\title{
Studies on the Adreno-Cortical Function of the Essential Hypertension By
}

\section{Toshihiko KISHI}

The Third Department of Internal Medicine, Nagoya, University School of Medicine

(Director : Prof. Dr. Kozo Yamada)

As to the patients suffering from the essential hypertension whose systolic pressure more than $150 \mathrm{mmHg}$, I measured the urinary total 17OHCS, 17KS and 17KS fraction, and administered ACTH Gel (14Units $\times 2$ ) to all of the cases, and with its variation examined the adreno-cortical reserve concretely and synthetically. And also investigated the connection of the adreno-cortical reserve with eosinophil response and other clinical observations.

There was no difference in particular between the hypertension patients and normal persons on the excretion quantities per day of urinary total 17OHCS, $17 \mathrm{KS}$ and the rate of increase on a day when ACTH administered. But observing the variation process of each of them during three days including ones just before and after the administration day, I recognized more so-called 'the type of abnormal responsiveness' showing the delay of increase or non-response among the hypertension patients. On the measurment of urinary $17 \mathrm{KS}$ fraction there was a tendency to increase IV V fraction among male patients of hypertension, and when administered ACTH the variations divided into three types; one showing III VI VII fraction increase, showing IV $V$ fraction increase, and fraction unvarying. As these variations have some constant connection with varied quantities of total $17 \mathrm{OHCS}$ and $17 \mathrm{KS}$ on the day of AGTH administration, the adreno-cortical function can be divided into three main types; sufficiency, comparative-insufficiency, and insufficiency. The types of insufficiency and comparativeinsufficiency have their causes in lowering of adreno-cortical responsiveness or impediment in cortical metabolism, and there have been occupied $70 \%$ of all the essential hypertension cases, which showed the lowering of cortical function. Among the $70 \%$ there are many cases in which hypertension has been continued during long term and also arteriosclerosis has particularly been in advanced stage. Their eosinophil responses, too, were much worse than others. 


\title{
本態性高血圧症の副腎皮質機能に就いて
}

\author{
名古屋大学医学部山田内科教室（指導 山田弘三教授） \\ 研究生 岸俊彦
}

本論文の要旨咕和 33 年 5 月 18 日第 31 回日本内分䎵学会総会, 昭和 34 年 4 月 6 日第 32 回日本内分泌学会総 会, 昭和 33 年 11 月 16 日第 3 回日本ジェロントロジー学会総会及び昭和 33 年 6 月 22 日第 6 回日本循環器学会東 海地方学会総会に於て発表した.

目次

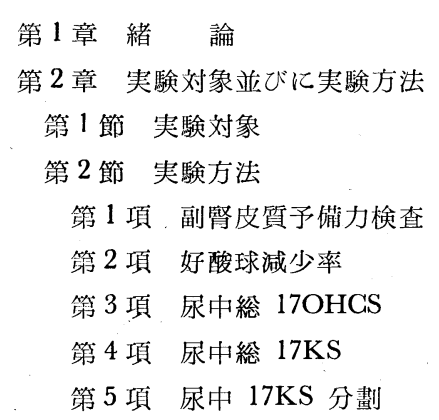

第 3 目 $17 \mathrm{KS}$ 分劃の ACTH 負荷に 上る変動

第 4 目 $17 \mathrm{KS}$ 分劃の恒常性

第 3 章 好酸球減少率について

第 1 節 序 言

第 2 節 実験成績

第 1 項健康人

第 2 項 本態性高血圧者

第 3 項 其の他疾患者

第 3 節 小 括

第 4 章 尿中総 17OHCS について

第 1 節 序 言

第 2 節 実験成䋶

第 1 項 健康人

第 2 項 本態性高血圧者

第 3 項 ACTH 負荷に上る尿中総 17

OHCS の変動と好酸球娍少率 との閶係
管 4 項 ACTH 負荷に上る尿中総 17 OHCS の変動推移

第 5 項 其の他疾患者

第 3 節 小 括

筇 5 章 尿中総 $17 \mathrm{KS}$ について

第 1 節 序 言

節 2 節 実験成繢

第 1 項 健 康人

第 2 項 本態性高血圧者

第 3 項 ACTH 負荷に上る尿中総 $17 \mathrm{KS}$ の変動と好酸球娍少率との関係

第 4 項 ACTH 負荷に上る尿中総 $17 \mathrm{KS}$ の変動推移

第 5 項 尿中総 $17 \mathrm{KS}$ と総 17OHCS と の關係

第 6 項 其の他疾患者

第 3 節 小 括

第 6 章 尿中 $17 \mathrm{KS}$ 分劃について

第 1 節 序 言

第 2 節 実験成績

第 1 項 健 康人

第 2 項 本態性高血圧者

第 3 項 ACTH 負荷比よる尿中 $17 \mathrm{KS}$ 分劃の変動と好酸球減少率との 関係

第 4 項 其の他疾患者

第 3 節 小 括

第 7 章 総括並び汇考按

第 8 章 結 論

文献 


\section{第 1 章 緒 論}

高血圧症は臨床的にはその原因に上り内分泌性，腎性或は本態性に大別されるが，乙れらの一次的昇圧因 子については精神神経興舊による血管運働神経過緊張，Stress に対する内分泌機能六進，遺层因子による血 管構造及び感受性異常等があげられているが，乙れら因子の一つのみで総ての高血圧症を説明することはで きない，臨床上所謂内分泌性高血圧症としてあげられるものには，下垂体副腎皮質機能充進による Cushing

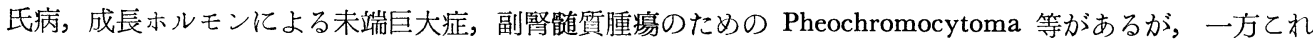
らを除く各種高血圧特に本態性高血圧症と下垂体副腎皮質系の関連については猶未解決の多くの問題を残し ている.

アドレナリン，ノルアドレナリンの昇圧作用に関する研究は最も古いが，その作用が一過性のため高血圧 の真の原因としては考えられなかつた，然るに近年 Long ${ }^{42)}$ ，Levine ${ }^{39)}$ 等は再びてれらは間脳中枢を介して高 血圧に関与するものと考元，更に Goldenberg ${ }^{27}$ 等はノルアドレナリン分泌增加が本症の真の原因の如く主張 している. 尤むてれい関しては von Euler ${ }^{22}$ の本態性高血圧者500例についてのノルアドレナリン測定成績に 於て増加を示すすのはわずか $16.4 \%$ にずないとして昇圧作用に対する否定的意見むある.

血圧調節に対して直接的に最も大きい影響をむつのは副腎皮質であり，てのととは1946年 Selye ${ }^{56)}$ が general adaptation syndrome なる概念のもとに高血圧症も亦下垂体副腎皮質系の過剩反応に基く之説いた ことに始まる。其後 Howard ${ }^{29)}$ ，Bowers ${ }^{8}$ 等は高血圧患者に副腎摘出を行い血圧の下降を認》，Green ${ }^{23}$ (は実 験的に動物に DOC 亡食塩を投与して高血圧をつくつた。 又下垂体摘出により血圧の降下をみている。 Leathem ${ }^{38}$ ，Wyman ${ }^{63}$ は犬大の副腎除去により低血圧を認め，更にてれに副腎ステロイドを投与して再び血圧の 上昇をおこしている. Anderson ${ }^{11}$ は下垂体剔除により低血圧をおこし，ACTH 投与でその恢復をみている。 更に Chwalla ${ }^{14}$ ，Locke ${ }^{41}$ 等は高血圧患者の副腎組織所見より皮質の肥大腫脹像を証明した。乙机らの報告は いづれも Selye の adaptation disease の概念適合するものの如く考元られる. 然るに一方に於て Tobian ${ }^{61}$ 汢本態性高血圧患者の尿中コルチコイドの排泄は正常範囲にあるとし，三宅 ${ }^{73}$ も本症患者の尿中 $17 \mathrm{KS}$ 值は 健常者と変らないと述べた。更に Bruger ${ }^{10}$ 等は高血圧婦人の尿中排泄 $17 \mathrm{KS}$ 值が正常婦人に較べ極めて低值

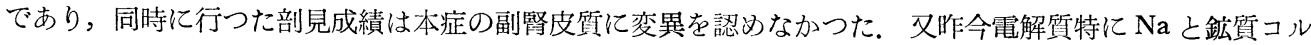
チコイドが本症の病因的役割に与る可能性の大きいととが指摘され，アルドステロンの研究も急速に進歩し た. Conn ${ }^{16)}$ は Primary aldosteronism で高血圧を合併すると述べ，Genest ${ }^{26)}$ は本態性高血圧症の尿中アルド ステロン排泄量が健康人より増加していると報告した，併し大島 ${ }^{81)}$ む述べる如く，ての面に関する研究む未 だ日浅く結論を出す段階には到らない，以上の如く高血圧発症と副腎皮質とは最む直接的な関係にあり，先 人の努力にも拘らず甲論乙駁帰一するところを知らない。

このととから，私は本態性高血圧症に於ける副腎皮質の意義に関して，ACTH 負荷時にみられる好酸球

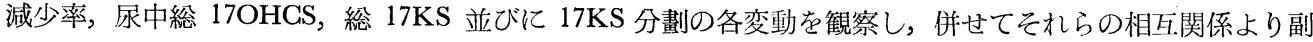
腎皮質機能（予備力）を綜合的に吟味し，一般臨床所見ともあわせ本態性高血圧症の内分泌環境について些 か検討を行つた.

\section{第 2 章＼cjkstart実験対象並びに実験方法}

\section{第 1 節 実験対象}

高血圧にて通院治療中の患者の中最高血圧 $150 \mathrm{~mm} \mathrm{Hg}$ ，最低血圧 $90 \mathrm{~mm} \mathrm{Hg}$ 以上の男女60例を対象とした. 西川 ${ }^{76}$ 力沭心゙る如く内分泌器官の年令的推移特に中年以後にみられる性腺機能脱落からくる副腎皮質機能の 複雑性を避ける意味で，本態性高血圧症を年代的に若年者と老年者に明確に区別し，若年者としては満39才 以下の男女を，老年者としては満 55 才以上满 75 才未满の男女を対象とし満 40 才以上満 54 才までの者は除外し た。諸検查実施にはすべて最低 1 週間の入院による安静と減塩食慨療法を実施し，尿中蛋白及び糖陽性者は

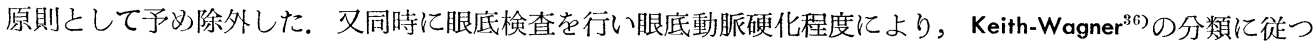


て I 度〜IV度に分類した。其他全例に心電図, 肝臟機能検查を行い比較検討した。尚対照として最高血圧 140 $\mathrm{mm}$ Hg以下の健康男女18例及び内分泌疾患，腎疾患，低血圧症患者で誩断確実なむのを数例選んだ。

\section{第 2 節 実験方法}

\section{第 1 項 副腎皮質予備力検查}

副㛑皮質機能検索に当り，尿中総 $17 \mathrm{OHCS}$ 及び総 $17 \mathrm{KS}$ 測定の意義は重要であるが，それらは正常範网 の広いこと或は日々変動のはげしい事等により若干の特殊疾患を除いてはとの 1 日排泄量のみを以て副腎皮 質機能を何うことはできない．所謂 Thorn’s Test は近年更に負荷前後のステロイドの変動を以て副掔皮質 予備力を伺うようになつた。功る予備力検查に於ては同時にその反応形式から下垂体性の二次的副腎皮質 機能不全か，原発性の副婜皮質機能不全かの鑑別も可能となりステロイド測定の意義も倍加した．私は患者 亿最む負担の少い Jenkins ${ }^{32}$ の ACTH Gel 2 回筋注法により副腎皮質予備力を検査した。 即ち H.P. ACTH $\mathrm{Gel}$ (Armour) 14単位 $(0.7 \mathrm{cc}$ ) 12 時間每: 2 回（午前 8 時及び午後 8 時）筋注，注射後12時間目（翌日4

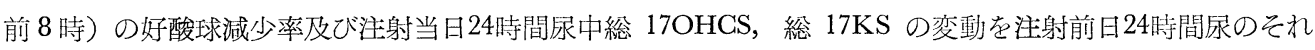
と比較した.

\section{第 2 項 好酸球減少率}

Bonner $^{7)}$, Rud ${ }^{53)}$ が述べる如く流血中好酸球数の日内変動はかなりはげしく，これを避ける意味でも ACTH Gel 2 回筋注法は優れ而も簡便である。Best ${ }^{4)}$ 亿ると流血中好酸球数の正常籍囲は $1 \mathrm{~mm}^{3}$ 中70 450であ るという。従つて私はこれ以上の好酸球增多を示す症例は子小除外した。

好酸球染色液は Hinkelman 氏液を使用し，好酸球数算定は同時にメランジュール2 本で採血しその平均値 をとつた.

\section{第3 項 尿中総 $17 \mathrm{OHCS}$}

尿中総 17OHCS 測定は，Reddy ${ }^{48}$ 等の原法に準じた鳥居 ${ }^{86)}$ の変法に従つた. 又前記の如く ACTH Gel を 負荷し注射当日及び注射翌日各 24 時間尿につき総 $17 \mathrm{OHCS}$ 排泄量を測定し前日尿のそれと比較，注射当日 尿については総 17OHCS 增堿量から副腎皮質予備力の程度を。連続 3 日間の排浛值より ACTH 負荷によ る総 17OHCS の变動推移を観察した。Pincus ${ }^{45}$ が述べる如く尿中及び血中の総 $17 \mathrm{OHCS}$ の日内变動はかな りはげしいたぬ24時間蓄尿は正確に午前 8 時から翌日の同時迄行うのを原則とした。

\section{第 4 項 尿中総 $17 \mathrm{KS}$}

尿中総 $17 \mathrm{KS}$ 測定は Drekter 法 ${ }^{21)}$ と Pearson 法 ${ }^{44}$ を併用した三宅变法 ${ }^{73}$ によつて行つた. 又前項と同じ操

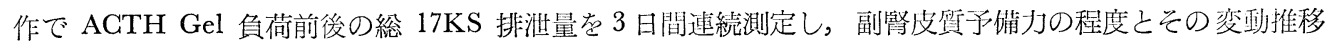
を観察した。

\section{第 5 項 尿中 $17 \mathrm{KS}$ 分劃}

第 1 目 尿中 $17 \mathrm{KS}$ 分劃測定法

尿中 $17 \mathrm{KS}$ 分劃測定法は1946年 Dingemanse $\left.{ }^{19},{ }^{19}\right)$ にり略々完成されたが。大量の溶媒を必要とする欠点 から Pond ${ }^{47)}$ ，Zygmuntowicz ${ }^{65)}$ ，Rosenkrantz ${ }^{52)}$ 等化よる microscale の方法が報告され，我国であ大野 ${ }^{79}$ ，安 達 ${ }^{66}$ 亿より臨床的に可能な方法が報告されている，私は Edwards，大野氏法に準じた教室興津 ${ }^{77) の ~ m i c r o s-~}$ cale elution chromatography により実施し，実験装置も教室興津考案の水圧法による簡易加圧溶出クロマ トグライィー装置を使用した.

第2目 クロマトグラフィーによる溶出部位

Dingemanse によると I 分劃は人工産物及び非ケトン分劃，II分劃は i-androstanolone，分劃は dehydroisoandrosterone，IV分劃は androsterone，V分劃は etiocholanolone，VI分劃は 11-hydroxyandrosterone， III分劃は 11-hydroxyetiocholanolone と報告したが，私の実験に於ても androsterone (AND) 及び

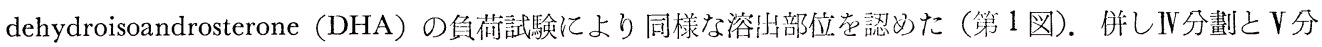
劃及びVI分劃と VII分劃は鋭利に分離しえなかつたが同様の代謝産物である故 $I V+V$ 分劃及びVI + VII分劃とし て合せて記載することにした。 


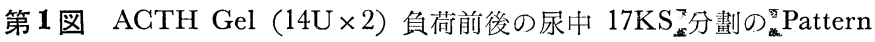

苦年健康人症例 2 . H.N. 壬

ACTH負荷前 $17 \mathrm{KS} 8.9 \mathrm{~m} \mathrm{~m} / \mathrm{\theta}$ 分㓻比 1.7

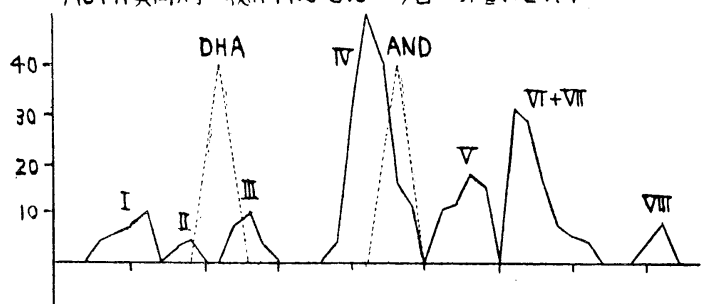

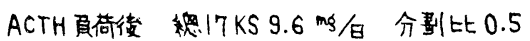
(注射望日)

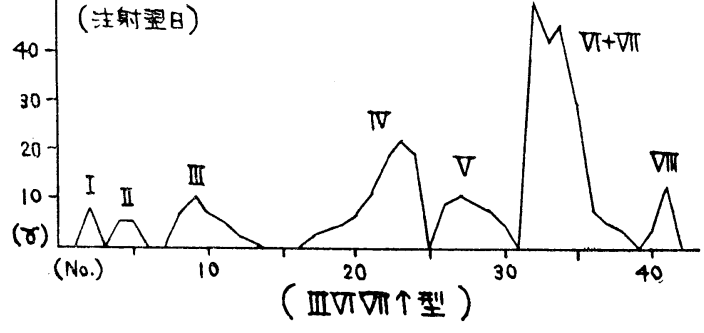

若年高血压者症例10.K.O. 令 ACTH頁荷前 㥎17 KS $8.2 \mathrm{mg} / \mathrm{g}$ 分剽 1.1

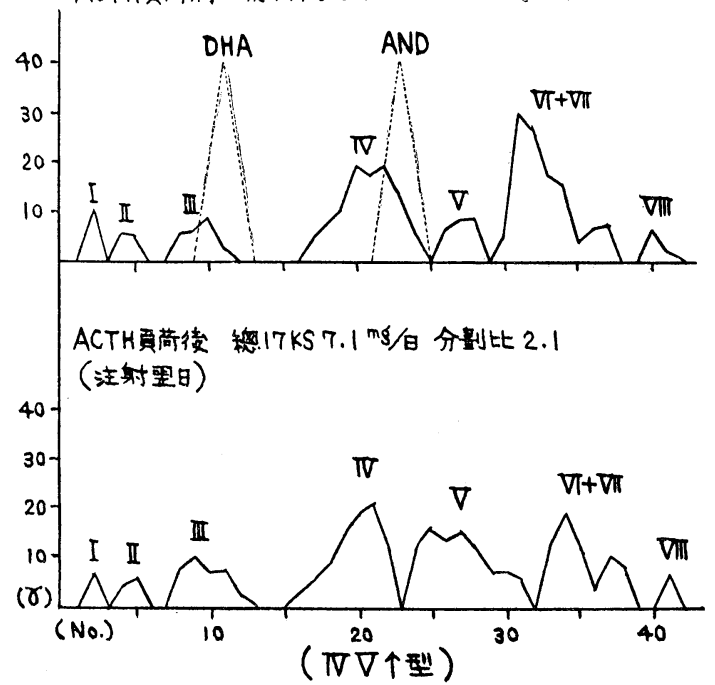

第3 目 $17 \mathrm{KS}$ 分劃の ACTH 負荷による变動

$17 \mathrm{KS}$ 分劃中IV及びV 分劃は androgen の代謝産物で一部 testosterone の代謝産物も含まれ， III 分劃， VI分劃及び汭分劃は glucocorticoid に由来するもので副腎皮質本来の代謝物といわれる，性腺系分劃（IV

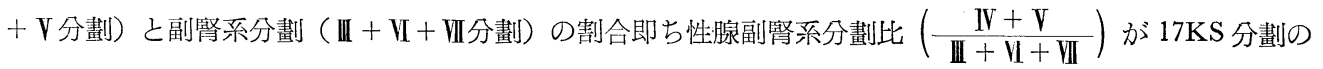
Pattern の決定に大きな要素になるととは当然である。前記 ACTH 負荷法により 17KS 分劃の Pattern が如何に変動するかを知るため，数例につき注射前日より連続 4 日間各24時間尿について主にその分劃比の 面から観察したところ (第 2 図)，ACTH 負荷により III + VI + VII分劃特にVI + VII分劃の 増加する型（以後 III IV VII 个型とする)，IV + V 分劃の増加する型 (以後 $\mathrm{V} V \uparrow$ 型とする) 並びに分劃に变動のない型 (以後不変 型とする)の三型がみられ，而子時間的変動推移をみると注射当日より注射翌日に Pattern の変動が明確に 現れるあの，或は注射当日に Pattern の変動はあるが注射翌々日に注射前の Pattern に速にもどるもの等 あることが分つた，かかる点より ACTH 負荷による $17 \mathrm{KS}$ 分劃の変動はすべて注射翌日24時間尿をすつ て前日尿と比較判定した (第 1 図). 尚 Pattern の立場から論ずるに便利のように 各分劃共その量を per cent で表した. 又 ACTH 負荷による变動值が等分劃共土 $5 \%$ を越す場合に限り変動あるものと判定した。

第 4 目 $17 \mathrm{KS}$ 分劃の恒常性

一般に各個人の有する $17 \mathrm{KS}$ 分劃の Pattern は恒常性を保つといわれるが，私も数例につき同一症例を 同一操作により最低 1 カ月の間隔をおき特に血圧值の異る二時期を選んで $17 \mathrm{KS}$ 分劃を測定し，それら Pattern の変動の有無を確めた（第 3 図）。総 $17 \mathrm{KS}$ 值は多少の変動があつたが，17KS 分劃は両時期共大 体同一Pattern を示し，性腚副腎系分劃比にも大差を認めず，血圧值とも特に関係がなかつた，かかる点よ り血圧動摇のはげしい高血圧者についても，17KS分劃測定に当り特に時期的考慮なしにその Pattern を決 定した.

\section{第 3 章 好酸球減少率について}

第 1 節 序 言 多くの副婜皮質機能検查の中で，間接的方法ではあるが最も簡便で而も広く routine 化されているのが 
第 2 図 ACTH Gel $(14 \mathrm{U} \times 2)$ 負荷による 尿中 $17 \mathrm{KS}$ 分劃の変動推移

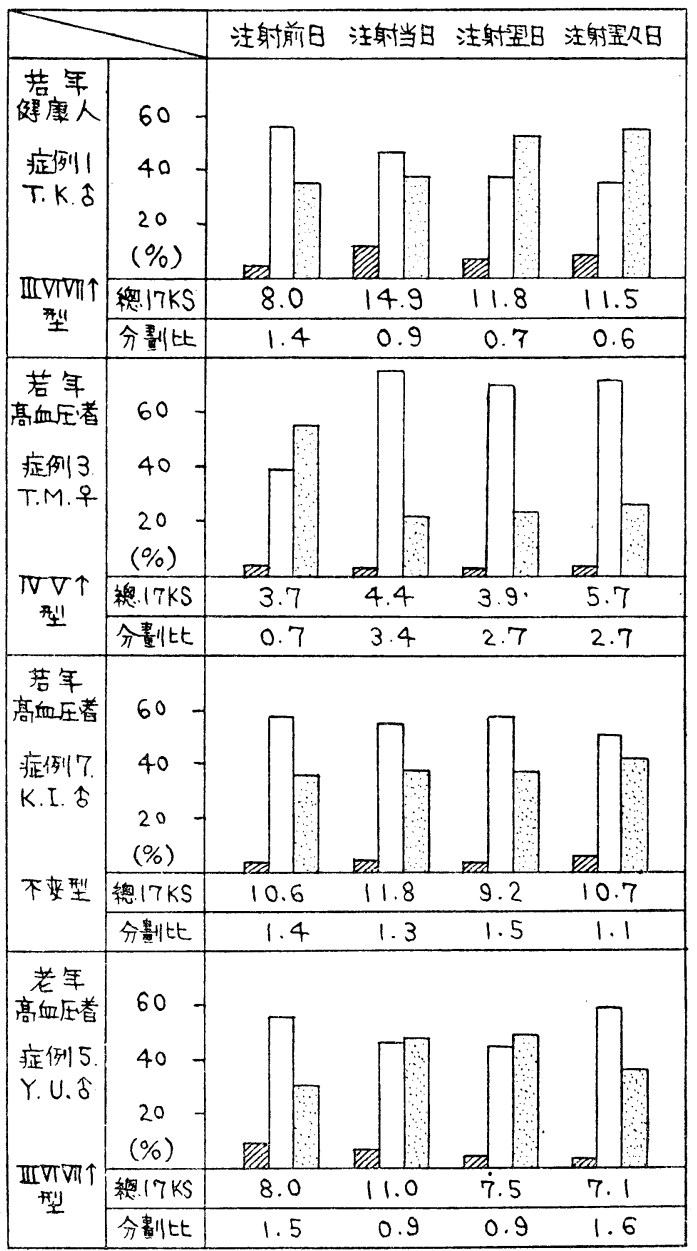

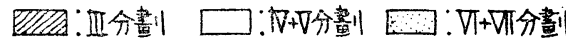

ACTH 負荷による 所謂 Thorn's Test であ る. 但し ACTH が血管外に於て異常に破壊 されたり，急性アレルギー疾患により著明な 好酸球増多を示す場合，或は好酸球の日差が 甚しい場合等には判断を誤らぬよう注意が必 要である。先に Thorn ${ }^{58}$ は ACTH 25mg 筋 注後 4 時間目の好酸球減少率及び尿酸・クレ アチニン比より所謂 rapid ACTH test を提 案し，其後も種々の变法が発表されたが，私 は生理的傎担の少い ACTH Gel 筋注法を採 用した。

\section{第 2 節 実験成績}

\section{第 1 項 健 康 人}

健康男女18例（若年者10例，老年者 8 例） について 検查したところ (第 1 表)，若年者 の好酸球減少率の变動範囲は-62〜-100\% であり，その平均はー87\%であつた，老年者 の動摇範罒はー12〜-82\%とその幅がやや㕕 く減少率平均はー $62 \%$ 之前者よりやや悪い. 男女别の相違をみる之（第 3 表），男女各 9 例の減少率平均は男子 $-81 \%$ ，女子-72\% と やや女子偠く，健康人全例の约酸球減少率 平均はー76\%であつた。

\section{第 2 項 本態性高血圧者}

本態性高血圧者男女60例（若年高血生:者33 例，老年高血圧者27例）について検查した之 こ万(第 2 表)，若年高血圧者の好酸球減少 率の変動範囲は＋5〜-99\%であり，その平 均はー54\%であつた。老年高血圧者の動摇範 柬は+ 5〜-96\% と前者同様その幅が広く減 少率平均はー $46 \%$ 之前者よりやや悪い, 男女 別の相䧼をみる之(第 3 表)，男子43例の減 少率平均はー $54 \%$ ，女子 17 例のそれはー $42 \%$ とやや女子に悪く，本態性高血圧者全例の好酸球減少率平均は - 50\%であつた.

\section{第 3 項 其の他疾患者}

2 例の神経性食思不振症患者，4例の慢性袩炎患者及び 3 例の低血圧症思考につき検査したとこ万（第 4 表)，それらの娍少率平均は神経性食思不振症ではー27\%，慢性腎炎ではー89\%，低血圧症ではー18\%と慢 性珡炎患者の減少率は良好であつた。

\section{第3 節 小 括}

流血中好酸球数の正常範囲については前述の如く $1 \mathrm{~mm}^{3}$ 中70 450とし，乙れを越すむのは子め除外した が，高血圧者60例中 $1 \mathrm{~mm}^{3}$ 中70以下のものが 7 例みられた。併しそれらの好酸球減少率，血圧值或は性之 の間の一定関係はなかつた，本態性高血圧者の好酸球減少率平均はー50\%であり，健康人の減少率平均-76 \%より明かに不良であつた，又健康人，高血圧者共に老年者は若年者に較べて減少率覀く，更に男女別平均 
第3 図 尿中 $17 \mathrm{KS}$ 分劃 Pattern の恒常性

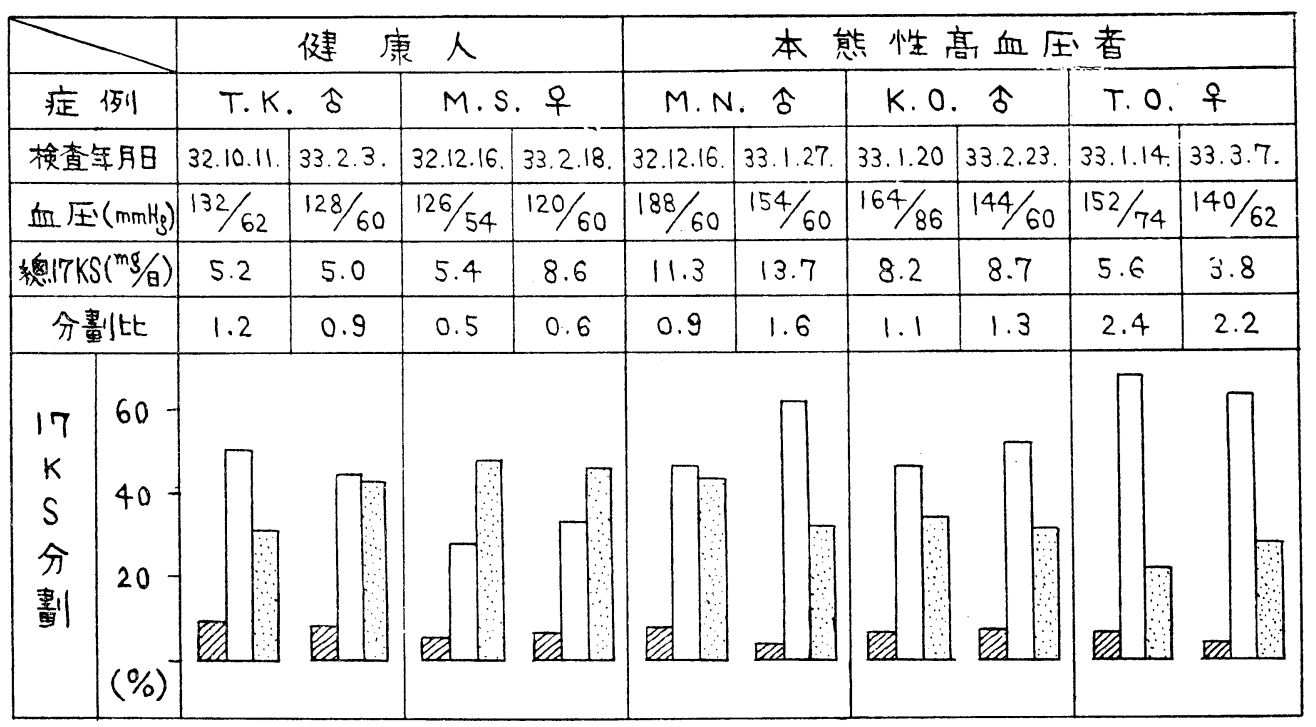

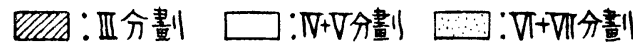

第1. 表 健康人の好酸球減少率（AGTH Gel $14 \mathrm{U} \times 2$ )

\begin{tabular}{|c|c|c|c|c|c|c|c|c|c|c|c|}
\hline \multicolumn{3}{|c|}{ 若 } & 年 & \multicolumn{2}{|l|}{ 者 } & \multicolumn{3}{|c|}{ 老 } & 年 & \multicolumn{2}{|l|}{ 者 } \\
\hline 症 & 例 & 性 & 血 圧 & 好酸球数 & 減少率 & 症 & 例 & 性 & 血 圧 & 好酸球数 & 減少率 \\
\hline 1 & T.K. & 今 & $126 / 60$ & 324 & -100 & 1 & H.K. & 우 & $112 / 60$ & 375 & -76 \\
\hline 2 & H.N. & 우 & $130 / 88$ & 206 & -62 & 2 & Y.K. & 우 & $108 / 62$ & 112 & -12 \\
\hline 3 & S.T. & $\hat{o}$ & $112 / 62$ & 104 & -89 & 3 & E.Y. & $\hat{o}$ & $132 / 70$ & 220 & -82 \\
\hline 4 & K. K. & 우 & $116 / 58$ & 330 & -100 & 4 & K.D. & $\hat{o}$ & $120 / 60$ & 380 & -80 \\
\hline 5 & $\mathrm{~S} . \mathrm{K}$. & $\hat{o}$ & $136 / 80$ & 415 & -92 & 5 & M. K. & 우 & $124 / 56$ & 425 & -68 \\
\hline 6 & M. S. & 우 & $110 / 52$ & 360 & -100 & 6 & $\mathrm{~T} . \mathrm{K}$. & 우 & $120 / 60$ & 247 & -68 \\
\hline 7 & S.M. & 우 & $124 / 60$ & 380 & -92 & 7 & $\mathrm{~T} . \mathrm{K}$. & 令 & $124 / 62$ & 158 & -63 \\
\hline 8 & M. S. & 占 & $112 / 60$ & 156 & -84 & 8 & H.M. & 令 & $128 / 20$ & 225 & -48 \\
\hline 9 & M. K. & 令 & $120 / 60$ & 320 & -88 & & & & & & \\
\hline 10 & $\mathrm{Y} . \mathrm{K}$. & 우 & $110 / 50$ & 112 & -68 & & & & & & \\
\hline \multicolumn{6}{|c|}{ 減少率平均 $-87 \%$} & \multicolumn{6}{|c|}{ 減少率平均 $-62 \%$} \\
\hline
\end{tabular}

第 2 表 高血圧者の好酸球減少率 (ACTH Gel $14 \mathrm{U} \times 2$ )

\begin{tabular}{|c|c|c|c|c|c|c|c|c|c|c|c|}
\hline \multicolumn{6}{|c|}{ 若年者本態性高血圧症 } & \multicolumn{6}{|c|}{ 老年者本態性高血圧症 } \\
\hline 症 & 例 & 性 & 血 圧 & 好酸球数 & 減少率 & 症 & 例 & 性 & 血 压 & 好酸球数 & 減少率 \\
\hline 1 & T.O. & 우 & $150 / 84$ & 63 & -25 & 1 & M. T. & o & $220 / 110$ & 250 & -80 \\
\hline 2 & Y.S. & $\hat{o}$ & $152 / 94$ & 164 & -22 & 2 & A.S. & $\hat{o}$ & $210 / 130$ & 126 & -31 \\
\hline 3 & T.M. & 우 & $160 / 100$ & 272 & -63 & 3 & S.U. & 우 & $150 / 80$ & 130 & -17 \\
\hline
\end{tabular}




\begin{tabular}{|c|c|c|c|c|c|c|c|c|c|c|c|}
\hline 4 & T.Z. & 㑒 & $168 / 100$ & 128 & -66 & 4 & S.H. & 令 & $162 / 94$ & 159 & -8 \\
\hline 5 & $\mathrm{~S} . \mathrm{T}$. & 占 & $160 / 90$ & 375 & -20 & 5 & Y.U. & $\hat{\delta}$ & $174 / 80$ & 78 & +5 \\
\hline 6 & H. E. & 今 & $164 / 94$ & 166 & -99 & 6 & Y. I. & $\hat{\delta}$ & $174 / 90$ & 150 & -96 \\
\hline 7 & K. I . & $\hat{o}$ & $168 / 88$ & 306 & -25 & 7 & S.Y. & $\hat{o}$ & $168 / 90$ & 220 & -88 \\
\hline 8 & K.U. & 今 & $180 / 100$ & 432 & -27 & 8 & H.Y. & $\hat{o}$ & $190 / 120$ & 125 & -65 \\
\hline 9 & M.N. & $\hat{o}$ & $180 / 110$ & 150 & -67 & 9 & T.Y. & 우 & $170 / 110$ & 69 & -38 \\
\hline 10 & K.O. & $\hat{o}$ & $164 / 80$ & 94 & -70 & 10 & G.O. & $\hat{o}$ & $152 / 86$ & 324 & -68 \\
\hline 11 & N.M. & $\hat{o}$ & $180 / 90$ & 125 & -58 & 11 & M.H. & $\hat{o}$ & $210 / 110$ & 228 & -27 \\
\hline 12 & N.K. & $\hat{o}$ & $180 / 80$ & 39 & -88 & 12 & M.M. & $\hat{\delta}$ & $220 / 100$ & 253 & -37 \\
\hline 13 & R.S. & $\hat{o}$ & $150 / 86$ & 344 & -39 & 13 & $\mathrm{~S} . \mathrm{K}$. & 今 & $200 / 110$ & 225 & -52 \\
\hline 14 & N.A. & $\hat{\delta}$ & $180 / 90$ & 91 & -93 & 14 & T.Y. & 우 & $174 / 102$ & 166 & -35 \\
\hline 15 & T.M. & $\hat{o}$ & $168 / 80$ & 155 & -69 & 15 & T.H. & 우 & $170 / 90$ & 166 & -38 \\
\hline 16 & E.O. & $\hat{o}$ & $160 / 86$ & 124 & -19 & 16 & T.Y. & 今̂ & $200 / 110$ & 334 & -89 \\
\hline 17 & S.Y. & 우 & $152 / 64$ & 304 & -68 & 17 & H.N. & 우 & $180 / 100$ & 450 & -35 \\
\hline 18 & T.S. & $\hat{o}$ & $164 / 90$ & 104 & -59 & 18 & M. T. & 우 & $164 / 84$ & 34 & -78 \\
\hline 19 & A.O. & $\hat{o}$ & $170 / 90$ & 278 & -76 & 19 & $\mathrm{~K} . \mathrm{K}$. & 우 & $220 / 120$ & 220 & -25 \\
\hline 20 & Y.Y. & $\hat{\delta}$ & $180 / 100$ & 290 & -18 & 20 & K.M. & 今 & $164 / 90$ & 185 & -22 \\
\hline 21 & S.Y. & $\hat{o}$ & $160 / 90$ & 412 & -85 & 21 & H.M. & 우 & $164 / 70$ & 366 & -70 \\
\hline 22 & M.Y. & $\hat{o}$ & $150 / 70$ & 390 & -74 & 22 & M. H. & 우 & $164 / 100$ & 445 & -68 \\
\hline 23 & A.M. & 우 & $152 / 94$ & 99 & -48 & 23 & $\mathrm{~K} . \mathrm{N}$. & 令 & $194 / 110$ & 15 & -6 \\
\hline 24 & M.M. & $\hat{\delta}$ & $170 / 100$ & 206 & -62 & 24 & Y. I. & 令 & $174 / 96$ & 318 & -52 \\
\hline 25 & H. H. & 우 & $154 / 88$ & 166 & -38 & 25 & S.O. & $\hat{\delta}$ & $160 / 80$ & 266 & -60 \\
\hline 26 & Y.K. & 우 & $154 / 90$ & 74 & -28 & 26 & T.M. & q & $200 / 110$ & 80 & -41 \\
\hline 27 & H.M. & $\hat{o}$ & $160 / 90$ & 164 & -72 & 27 & K. Y. & 㑒 & $170 / 90$ & 225 & -30 \\
\hline 28 & M.O. & $\hat{o}$ & $160 / 100$ & 350 & -38 & & & & & & \\
\hline 29 & M.K. & 우 & $200 / 130$ & 147 & +5 & & & & & & \\
\hline 30 & K.S. & $\hat{o}$ & $150 / 88$ & 31 & -75 & & & & & & \\
\hline 31 & S.Y. & 㑒 & $156 / 90$ & 135 & -88 & & & & & & \\
\hline 32 & $\mathrm{~K} . \mathrm{K}$. & $\hat{o}$ & $174 / 70$ & 66 & -62 & & & & & & \\
\hline 33 & S.S. & $\hat{o}$ & $164 / 90$ & 84 & -38 & & & & & & \\
\hline \multicolumn{6}{|c|}{ 減少率平均 $-54 \%$} & \multicolumn{6}{|c|}{ 娍少率平均 $-46 \%$} \\
\hline
\end{tabular}

第 3 表 健康人及び高血圧者の男女別好酸球減少率

\begin{tabular}{|c|c|c|c|c|c|c|c|}
\hline \multirow[b]{2}{*}{ 健 康 人 } & \multirow{2}{*}{$\begin{array}{l}\text { 性 } \\
\text { 今 } \\
\text { 우 }\end{array}$} & \multirow{2}{*}{$\begin{array}{l}\text { 例 } \\
9 \\
9\end{array}$} & \multirow{2}{*}{$\frac{\text { 数 }}{18}$} & \multirow{2}{*}{$\begin{array}{c}\text { 動 摇 範 } \\
-63 \sim-100 \\
-12 \sim-100\end{array}$} & \multirow{2}{*}{$\frac{\text { 囲 (\%) }}{-12 \sim-100}$} & \multicolumn{2}{|c|}{ 減少率平均 $(\%)$} \\
\hline & & & & & & $\begin{array}{l}-81 \\
-72\end{array}$ & -76 \\
\hline 高血压者 & $\begin{array}{l}\text { 京 } \\
\text { 우 }\end{array}$ & $\begin{array}{l}43 \\
17\end{array}$ & 60 & $\begin{array}{l}+5 \sim-99 \\
+5 \sim-78\end{array}$ & $+5 \sim-99$ & $\begin{array}{l}-54 \\
-42\end{array}$ & -50 \\
\hline
\end{tabular}

值に於ては女子の方が減少率が恵かつた。尚数例の其の他疾患考についても検討したが，慢性婜炎の減少率 は良好であつた。 
第 4 表 其の他疾患者の好酸球減少率 (ACTH Gel $14 \mathrm{U} \times 2$ )

\begin{tabular}{|c|c|c|c|c|c|c|}
\hline & 症 & 例 & 性 & 血 圧 & 好酸球数 & 減少率 \\
\hline \multirow{3}{*}{$\begin{array}{l}\text { 神思 } \\
\text { 経不 } \\
\text { 性振 } \\
\text { 食症 }\end{array}$} & 1 & K. A. & 우 & $112 / 60$ & 98 & -26 \\
\hline & & $\mathrm{Y} . \mathrm{O}$. & $\hat{\delta}$ & $124 / 62$ & 181 & -29 \\
\hline & \multicolumn{6}{|c|}{ 減少率平均 $-27 \%$} \\
\hline \multirow{5}{*}{$\begin{array}{l}\text { 慢 } \\
\text { 性 } \\
\text { 腎 } \\
\text { 炎 }\end{array}$} & 1 & M.K. & 우 & $144 / 74$ & 260 & -87 \\
\hline & 2 & N.H. & 우 & $136 / 70$ & 384 & -100 \\
\hline & 3 & $\mathrm{~K} . \mathrm{O}$ & $\hat{\delta}$ & $160 / 80$ & 154 & -73 \\
\hline & 4 & S.Y. & $\hat{\delta}$ & $154 / 74$ & 390 & -95 \\
\hline & \multicolumn{6}{|c|}{ 減少率平均 $-89 \%$} \\
\hline \multirow{4}{*}{$\begin{array}{l}\text { 低 } \\
\text { 血 } \\
\text { 底 } \\
\text { 症 }\end{array}$} & 1 & A.N. & 움 & $96 / 60$ & 63 & -16 \\
\hline & 2 & Y.S. & 우 & $90 / 50$ & 128 & +15 \\
\hline & & $\mathrm{T} . \mathrm{Y}$. & $\hat{o}$ & $96 / 40$ & 110 & -52 \\
\hline & \multicolumn{6}{|c|}{ 減少率平均 $\quad-18 \%$} \\
\hline
\end{tabular}

\section{第 4 章 尿中総 17OHCS}

について

\section{第 1 節 序 言}

尿中にグルクロン酸を抱合した型で比 較的多量の corticoid が排泄されている ことは Bhuler ${ }^{5)}$, Venning ${ }^{62)}$, Cohen ${ }^{15}$ )等に よつて夙伯指摘されていた，并の本態が tetrahydrohydrocortisone であるととは Bagget ${ }^{2}$ )等 (1953) が確認した所である. 然るにてれより先 Reddy ${ }^{48}$ 等 (1952) は かかる水溶性 corticoid をブタノールで 抽出し，之にPorter 法を配して上記抱合 型を含めこの主要代謝産物の測定法を提 案したが，本定量法は実施上種々の難点 があり，その後色々の改良法 ${ }^{57},{ }^{300}$ が報告 された。私は Reddy 等の原法に準じた鳥 居 ${ }^{86)}$ の変法により尿中総 $17 \mathrm{OHCS}$ を測定した，副婜皮質子矠力検査としての尿中総 $17 \mathrm{OHCS}$ 值の意義は 又重大であり，Thorn ${ }^{60)}$ 快 Stress 時のステロイド反応系の態度に於て，17OHCS は 17KS より sensitive で glucocorticoid activity の尺度として最も意義あるあのと述へている. 又尿中総 $17 \mathrm{OHCS}$ の日内変覒につ いては Pincus ${ }^{45}$ ，Romanoff ${ }^{511}$ の研究があるが，Forsham ${ }^{24)}$ はかかる日内変動にとあない ACTH 負荷による尿 中総 17OHCS の反応態度も異ると述べてる。ACTH Gel 2 回筋注法はかかる意味に於ても適切且簡便 な負荷法と考元る。尚尿中に排泄されるグルクロン酸抱合体は大部分肝に於て合成されるので，若し肝障碍 があれば Brown?，Birke (6)の述べる如く尿中総 17OHCS 值並びに総 17KS 值は低下寸る，私はかかる意味 で全例に肝機能を実施し，著明な肝機能障碍者は予め除外した。

\section{第 2 節 実験成績}

\section{第 1 項 健 康 人}

侓康男女10例（若年考 2 例，老年者 8 例）について检查したととろ（第 5 表 $\mathrm{a} ， \mathrm{~b}$ )，若年者の尿中総17 OHCS 值の平均は $6.7 \mathrm{mg} /$ 日, ACTH 負荷当日の增量平均は $+11.6 \mathrm{mg} /$ 日 であつた。老年者の㽷中総 17 OHCS 值の平均は $7.4 \mathrm{mg} /$ 日，ACTH 負荷当日の增量平均は $+8.4 \mathrm{mg} /$ 日であり若年者と大差がない，男女 別の相違は (第 6 表)，男女各 5 例の総 $17 \mathrm{OHCS}$ 值の平均は男子 $8.0 \mathrm{mg} /$ 日，女子 $6.5 \mathrm{mg} /$ 日とやや女子に 低值右示し。ACTH 負荷当日の增量平均も男子 $+10.0 \mathrm{mg} /$ 日，女子 $+8.1 \mathrm{mg} /$ 日と女子の增量は少ない。尚 健康人全例の尿中総 $17 \mathrm{OHCS}$ 值の平均は $7.2 \mathrm{mg} /$ 日， ACTH 負荷当日の增量平均は $+9.1 \mathrm{mg} /$ 日であつた。

\section{第 2 項 本態性高血圧者}

木態性高血圧考男女43例（若年高血圧者16例，老年高血圧者27例）を検査した結果（第 7 表 a， b ），若 年高血厌者の尿中総 $17 \mathrm{OHCS}$ 值の平均は7.2mg/日, ACTH 負荷当日の増量平均は $+6.9 \mathrm{mg} /$ 日であつた. 老年高血压者の尿中総 $17 \mathrm{OHCS}$ 俻の平均は $8.1 \mathrm{mg} /$ 日， $\mathrm{ACTH}$ 負荷当日の增量平均は $+8.2 \mathrm{mg} /$ 日 若年 高血圧者との間に有意の差はみられない，男女別の相違をみると（第 6 表），男子 29 例，女子14例について 総 $17 \mathrm{OHCS}$ 值の臣均は男子 $8.0 \mathrm{mg} /$ 日，女子 $6.6 \mathrm{mg} /$ 日とやや女子に低值を示し，ACTH 負荷当日の增量 平均屯男子 $+8.1 \mathrm{mg} /$ 日，女子 $+6.8 \mathrm{mg} /$ 日と女子の増量は少ない．尚本態性高血圧者全例の尿中総 $17 \mathrm{OHCS}$ 做の平均は $7.5 \mathrm{mg} /$ 日, ACTH 負荷当日の増量平均は $+7.7 \mathrm{mg} /$ 日であつた。

第 3 項 ACTH 負苛による尿中総 $17 \mathrm{OHCS}$ の変動之好酸球減少率之の関係

ACTH 負荷当日の総 $17 \mathrm{OHCS}$ 增減量と好酸球減少率との関係を若年及び老年者別にふると（第４図）， 
第 5 表 健康人の副腎皮質子備力（ACTH Gel $14 \mathrm{U} \times 2$ )

a.（若年健康人）

\begin{tabular}{|c|c|c|c|c|c|c|c|c|c|c|c|}
\hline \multirow[b]{2}{*}{ 症 例 } & \multirow{2}{*}{ 性 } & \multirow{2}{*}{$\begin{array}{l}\text { 平好酸球 } \\
\text { 減少率 } \\
(\%)\end{array}$} & \multicolumn{2}{|c|}{$\begin{array}{l}\text { 総 17OHCS } \\
\text { (mg/日) }\end{array}$} & \multicolumn{2}{|c|}{$\begin{array}{l}\text { 総 17KS } \\
(\mathrm{mg} / \text { 日) }\end{array}$} & \multicolumn{2}{|r|}{ 臨 } & 床 & 所 & 見 \\
\hline & & & $\begin{array}{c}\text { 旦 } \\
\text { 排泄 } \\
\text { 量 }\end{array}$ & $\begin{array}{l}\text { ACTH } \\
\text { による } \\
\text { 変動值 }\end{array}$ & $\left|\begin{array}{c}1 \text { 日 } \\
\text { 排泄 } \\
\text { 量 }\end{array}\right|$ & $\begin{array}{l}\text { ACTH } \\
\text { にょる } \\
\text { 変動值 } \\
\end{array}$ & $\underset{(\mathrm{mmHg})}{\text { 血 }}$ & $\begin{array}{l}\text { 心電図 } \\
\text { 所 見 }\end{array}$ & \begin{tabular}{|c|} 
眼底 \\
所見 \\
(K.W.) \\
\end{tabular} & $\begin{array}{c}\text { 肝 機 能 } \\
\text { (BSP 及びコ } \\
\text { バルト反応 }\end{array}$ & 其 の 他 \\
\hline $\mathrm{T} . \mathrm{K}$. & $\hat{\delta} 27$ & -100 & & & 8.0 & +6.9 & $426 / 60$ & 正常 & I & $5 \%: \mathrm{R}_{2(5)}$ & \\
\hline H.N. & 우 23 & -62 & & & 8.9 & +1.9 & $130 / 88$ & 正常 & I & $2.5 \%: \mathrm{R}_{3(5)}$ & 時に尿蛋白 $( \pm)$ \\
\hline $\mathrm{S} . \mathrm{T}$. & $\begin{array}{lll}\hat{\delta} & 30\end{array}$ & -89 & & & 6.4 & +3.8 & $112 / 62$ & 正常 & I & $0 \%: \mathrm{R}_{2(3)}$ & \\
\hline $\mathrm{K} . \mathrm{K}$. & 우 26 & -100 & & & 5.2 & +1.4 & $116 / 58$ & & & & \\
\hline S.K. & 令 33 & -92 & & & 7.9 & +0.5 & $136 / 80$ & 正常 & I & $0 \%: \mathrm{R}_{4(6)}$ & 時江尿蛋白 $( \pm)$ \\
\hline M.S. & 우 21 & -100 & & & 5.4 & +2.3 & $110 / 52$ & 正常 & I & $2.5 \%: \mathrm{R}_{2(3)}$ & \\
\hline S.M. & 우 22 & -92 & & & 8.6 & +1.6 & $124 / 60$ & & I & $0 \%: \mathrm{R}_{3(5)}$ & \\
\hline M. S. & 今: 28 & -84 & & & 5.6 & +2.3 & $112 / 60$ & & I & & \\
\hline M.K. & 负 21 & -88 & 7.8 & +13.5 & 7.5 & +5.0 & $120 / 60$ & 正常 & I & $5 \%: \mathrm{R}_{3}$ & \\
\hline Y.K. & $\mid+25$ & -68 & 5.5 & +9.7 & 6.2 & +3.7 & $110 / 50$ & 正常 & I & $0 \%:$ & \\
\hline 平均 & 值 & -87 & 6.7 & +11.6 & 7.0 & +2.9 & & & & & \\
\hline
\end{tabular}

\section{b.（老年健康人）}

\begin{tabular}{|c|c|c|c|c|c|c|c|c|c|c|c|}
\hline \multirow[b]{2}{*}{ 症 例 } & \multirow{2}{*}{ 年 } & \multirow{2}{*}{$\begin{array}{c}\text { 好酸球 } \\
\text { 減少棌 } \\
(\%)\end{array}$} & \multicolumn{2}{|c|}{$\begin{array}{l}\text { 総 17OHCS } \\
\text { (mg/日) }\end{array}$} & \multicolumn{2}{|c|}{$\begin{array}{l}\text { 総 } 17 \mathrm{KS} \\
(\mathrm{mg} / \text { 日 })\end{array}$} & \multicolumn{2}{|r|}{ 臨 } & 床 & 所 & 見 \\
\hline & & & $\mid \begin{array}{c}1 \text { 日 } \\
\text { 排泄 } \\
\text { 量 }\end{array}$ & $\begin{array}{l}\text { ACTH } \\
\text { による } \\
\text { 変動値 }\end{array}$ & $\left|\begin{array}{c}1 \\
\text { 日 } \\
\text { 排泄 } \\
\text { 量 }\end{array}\right|$ & $\begin{array}{l}\text { ACTH } \\
\text { による } \\
\text { 変動値 }\end{array}$ & $\underset{(\mathrm{mmHg})}{\text { 血 }}$ & $\begin{array}{l}\text { 心電図 } \\
\text { 所 見 }\end{array}$ & \begin{tabular}{|c|} 
眼底 \\
所見 \\
(K.W.) \\
\end{tabular} & $\left(\begin{array}{c}\text { 肝 機 能 } \\
\text { BSP 及びコ } \\
\text { バルト反応 }\end{array}\right)$ & 其 の \\
\hline H.K. & + 52 & -76 & 6.3 & +5.9 & 4.7 & +0.9 & $112 / 60$ & 正常 & I & $5 \%: \mathrm{R}_{3(4)}$ & \\
\hline $\mathrm{Y} . \mathrm{K}$. & 우 54 & -12 & 3.3 & +2.9 & 5.1 & +0.4 & $108 / 62$ & 低電位差 & I & $0 \%: \mathrm{R}_{2(3)}$ & \\
\hline E.Y. & 令 51 & -82 & 8.6 & +9.6 & 5.2 & +1.6 & $132 / 70$ & 正常 & I & $2.5 \%: \mathrm{R}_{3}$ & 慢性胃炎 \\
\hline K.D. & 今 66 & -80 & 10.3 & +9.2 & 10.2 & +0.6 & $120 / 60$ & 正常 & I & $0 \%:$ & 時に尿蛋白 $( \pm)$ \\
\hline M.K. & 우 50 & -68 & 9.4 & +13.3 & 4.6 & +2.0 & $124 / 56$ & 正常 & I & $0 \%: \mathrm{R}_{3(4)}$ & \\
\hline $\mathrm{T} . \mathrm{K}$. & 우 53 & -68 & 7.9 & +8.7 & 7.0 & +0.4 & $120 / 60$ & & I & $2.5 \%:$ & \\
\hline T.K. & 含 71 & -63 & 7.2 & +11.8 & 7.0 & +2.1 & $124 / 62$ & 肺性 P & I & & \\
\hline 8 H.M. & 令 57 & -48 & 5.9 & +5.9 & 7.1 & +1.5 & $128 / 50$ & 正常 & & $2.5 \%: \mathrm{R}_{4}$ & 貧血症 \\
\hline 平均 & 值 & -62 & 7.4 & +8.4 & 6.4 & +1.2 & & & & & \\
\hline
\end{tabular}

第 6 表 健康人及び高血圧者の男女別尿中総 $17 \mathrm{OHCS}$ 值

\begin{tabular}{|c|c|c|c|c|c|c|c|}
\hline \multirow[b]{2}{*}{ 健康人 } & \multirow{2}{*}{$\begin{array}{l}\text { 性 } \\
\text { 㑒 } \\
\text { 우 }\end{array}$} & \multirow{2}{*}{$\begin{array}{l}\text { 例 } \\
5 \\
5\end{array}$} & \multirow{2}{*}{$\frac{\text { 数 }}{10}$} & \multicolumn{2}{|c|}{$\begin{array}{c}1 \text { 日排泄量平均 } \\
(\mathrm{mg} / \text { 日 })\end{array}$} & \multicolumn{2}{|c|}{$\begin{array}{c}\text { AGTH による増量平均 } \\
(\mathrm{mg} / \text { 旦 })\end{array}$} \\
\hline & & & & $\begin{array}{l}8.0 \\
6.5\end{array}$ & 7.2 & $\begin{array}{r}+10.0 \\
+8.1\end{array}$ & +9.1 \\
\hline 高血压者 & $\begin{array}{l}\text { 个 } \\
\text { 우 }\end{array}$ & $\begin{array}{l}29 \\
14\end{array}$ & 43 & $\begin{array}{l}8.0 \\
6.6\end{array}$ & 7.5 & $\begin{array}{l}+8.1 \\
+6.8\end{array}$ & +7.7 \\
\hline
\end{tabular}


第 7 表 a. 若年者本態性高血圧症の副腎皮質予供力（ACTH Gel $14 \mathrm{U} \times 2)$

\begin{tabular}{|c|c|c|c|c|c|c|c|c|c|c|c|c|}
\hline \multirow[b]{2}{*}{ 症 } & \multirow[b]{2}{*}{ 例 } & \multirow{2}{*}{ 年 } & \multirow{2}{*}{$\begin{array}{l}\text { 好酸球 } \\
\text { 減少率 } \\
(\%)\end{array}$} & \multicolumn{2}{|c|}{\begin{tabular}{|l} 
総 17OHCS \\
(mg/日)
\end{tabular}} & \multicolumn{2}{|c|}{$\begin{array}{l}\text { 総 } 17 \mathrm{KS} \\
(\mathrm{mg} / \text { 日) }\end{array}$} & \multicolumn{2}{|r|}{ 臨 } & 床 & 所 & 見 \\
\hline & & & & \begin{tabular}{|c|}
1 日 \\
排淤 \\
量
\end{tabular} & $\begin{array}{c}\mathrm{ACTH} \\
\text { による } \\
\text { 変動値 }\end{array}$ & $\left|\begin{array}{c}1 \text { 日 } \\
\text { 排浛 } \\
\text { 最 }\end{array}\right|$ & $\begin{array}{l}\text { ACTH } \\
\text { による } \\
\text { 変動値 } \\
\end{array}$ & $\underset{(\mathrm{mmHg})}{\text { 血 }}$ & $\begin{array}{l}\text { 心電図 } \\
\text { 所 見 }\end{array}$ & \begin{tabular}{|c|} 
眼底 \\
所見 \\
(K.W.) \\
\end{tabular} & $\left(\begin{array}{c}\text { 肝 機 能 } \\
\text { BSP 及びコ } \\
\text { バルト反応 }\end{array}\right)$ & 其 の \\
\hline 1 & T.O. & 우 $28 \mid$ & -25 & & & 5.6 & +1.9 & $150 / 84$ & 正常 & I & $5 \%: \mathrm{R}_{4(5)}$ & \\
\hline 2 & Y.S. & 今 30 & -22 & & & 3.8 & +1.4 & $152 / 94$ & 正常 & I & $2.5 \%: \mathrm{R}_{2(3)}$ & \\
\hline 3 & T.M. & 우 23 & -63 & & & 3.7 & +0.7 & $160 / 100$ & 正常 & I & $5 \%: \mathrm{R}_{3(4)}$ & \\
\hline 4 & T.Z. & 今 28 & -66 & & & 10.2 & +1.8 & $168 / 100$ & 正常 & I & $10 \%: \mathrm{R}_{3}$ & \\
\hline 5 & $\mathrm{~S} . \mathrm{T}$. & $\hat{\delta}$ & -20 & & & 11.6 & +2.1 & $160 / 90$ & 正常 & II & $7.5 \%:$ & \\
\hline 6 & H.E. & 今ิ 35 & -99 & & & 7.5 & +4.7 & $164 / 94$ & & II & $2.5 \%: \mathrm{R}_{3}$ & \\
\hline 7 & K. I. & $\hat{o} 27$ & -25 & & & 10.6 & +1.1 & $168 / 88$ & 正常 & I & $5 \%: \mathrm{R}_{3}$ & \\
\hline 8 & $\mathrm{~K} . \mathrm{U}$. & 今 37 & -27 & & & 6.1 & +0.2 & $180 / 100$ & $\begin{array}{l}\text { 時に } \\
\text { 期外収縮 }\end{array}$ & II & $5 \%: \mathrm{R}_{3(\tilde{s})}$ & \\
\hline 9 & M.N. & $\begin{array}{ll}\hat{\jmath} & 19 \\
\end{array}$ & -67 & & & 11.3 & +3.2 & $180 / 110$ & 正常 & I & $7.5 \%: \mathrm{R}_{3(4)}$ & \\
\hline 10 & $\mathrm{~K} . \mathrm{O}$. & 今 30 & -70 & & & 8.2 & -0.8 & $164 / 80$ & & I & $0 \%: \mathrm{R}_{4}$ & \\
\hline 11 & N.M. & \begin{tabular}{l|l|l|} 
& 1 & 22 \\
\end{tabular} & -58 & & & 16.4 & +3.1 & $180 / 90$ & 正常 & $\mathrm{I}$ & $0 \%: \mathrm{R}_{2(3)}$ & \\
\hline 12 & N.K. & $\hat{o} 21$ & -88 & & & 7.9 & +9.4 & $180 / 80$ & 正常 & $\mathrm{I}$ & $10 \%: \mathrm{R}_{3(4)}$ & \\
\hline 13 & R.S. & \begin{tabular}{|l|l|}
$\hat{o}$ & 31 \\
\end{tabular} & -38 & & & 4.2 & +0.5 & $150 / 86$ & 正常 & I & $0 \%: \mathrm{R}_{3(4)}$ & 時に尿蛋白 $( \pm)$ \\
\hline 14 & N.A. & $\hat{\circ} \mid 22$ & -93 & & & 8.7 & +0.6 & $180 / 90$ & 正常 & I & $0 \%: \mathrm{R}_{3}$ & \\
\hline 15 & T.M. & $\hat{\delta} 25$ & -69 & & & 6.9 & +1.8 & $168 / 80$ & 正常 & I & $5 \%: \mathrm{R}_{3(4)}$ & \\
\hline 16 & E.O. & $\begin{array}{lll}\hat{\delta} & 30\end{array}$ & -19 & & & 8.1 & +2.4 & $160 / 86$ & 正常 & I & $5 \%: \mathrm{R}_{3}$ & \\
\hline 17 & S.Y. & 우 25 & -68 & & & 6.2 & +1.6 & $152 / 64$ & & I & $0 \%:$ & \\
\hline 18 & $\mathrm{~T} . \mathrm{S}$ & 今人 20 & -59 & 9.0 & +3.2 & 5.7 & -0.2 & $164 / 90$ & 正常 & & $5 \%: \mathrm{R}_{2(3)}$ & 時に尿蛋白 (土) \\
\hline 19 & A.O. & $\boldsymbol{\delta} 20$ & -76 & 6.8 & +9.4 & 8.3 & +3.1 & $170 / 90$ & & I & $2.5 \%: \mathrm{R}_{3}$ & \\
\hline 20 & $Y . Y$ & \begin{tabular}{l|l}
$\hat{0}$ & 18
\end{tabular} & -18 & 3.7 & +1.2 & 4.5 & -1.9 & $180 / 100$ & $\begin{array}{l}\text { QRS } \\
\text { 延長左 } \\
\text { 室肥大 }\end{array}$ & III & $10 \%: \mathrm{R}_{3(4)}$ & \\
\hline 21 & S.Y. & $\begin{array}{lll}\hat{\circ} & 20\end{array}$ & -85 & 8.4 & +16.6 & 10.2 & +2.9 & $160 / 90$ & 正常 & I & $5 \%:$ & \\
\hline 22 & M. Y. & $\begin{array}{lll}\hat{\delta} & 18\end{array}$ & -74 & 1.0 & +3.2 & 3.4 & +0.2 & $150 / 70$ & 期外収縮 & I & $0 \%:$ & \\
\hline 23 & A.M. & 우 22 & -48 & 7.9 & +4.2 & 4.8 & +0.8 & $152 / 94$ & 正常 & I & $7.5 \%: \mathrm{R}_{5}$ & \\
\hline 24 & M.M. & 今 38 & -62 & 8.4 & +2.4 & 3.7 & +2.1 & $170 / 100$ & $\begin{array}{l}\mathrm{ST}_{\mathrm{II}} \\
\text { 低下 }\end{array}$ & II & $10 \%: \mathrm{R}_{3(4)}$ & \\
\hline 25 & H.H. & 30 & -38 & 6.3 & +5.2 & 10.6 & +2.2 & $134 / 88$ & & I & $0 \%:$ & \\
\hline 26 & $\mathrm{Y} . \mathrm{K}$. & 우 23 & -28 & 8.7 & +11.7 & 5.4 & +1.2 & $154 / 90$ & 正常 & I & & \\
\hline 27 & H.M. & \begin{tabular}{l|l}
$\hat{\diamond}$ & 18 \\
\end{tabular} & -72 & 4.3 & +4.4 & 3.4 & +2.1 & $160 / 90$ & & & $0 \%: \mathrm{R}_{2(1)}$ & \\
\hline 28 & M.O. & $\hat{0} 26$ & -38 & 11.9 & +4.7 & 9.2 & +1.5 & $160 / 100$ & 正常 & $\mathrm{I}$ & $2.5 \%: \mathrm{R}_{3}$ & \\
\hline 29 & M.K. & 우 36 & +5 & 4.8 & +0.2 & 2.2 & -0.9 & $200 / 130$ & $\begin{array}{c}\mathrm{ST}_{\text {II III }} \\
\text { 低下 }\end{array}$ & II & $5 \%: \mathrm{R}_{5}$ & $\begin{array}{l}\text { 脳出血 } \\
\text { 泉蛋白 }( \pm)\end{array}$ \\
\hline 30 & $\mathrm{~K} \cdot \mathrm{S}$ & \begin{tabular}{l|l}
$\hat{\delta}$ & 19
\end{tabular} & -75 & 11.6 & +15.3 & 14.8 & +4.7 & $150 / 88$ & 正常 & I & $5 \%:$ & \\
\hline 31 & S. Y. & $\hat{\delta} 27$ & -88 & 9.4 & +12.5 & 9.4 & +2.6 & $156 / 90$ & 正常 & I & $0 \%: \mathrm{R}_{2(3)}$ & \\
\hline 32 & $\mathrm{~K} \cdot \mathrm{K}$ & $\hat{o} 28$ & -62 & 8.4 & +4.1 & 6.7 & -0.6 & $174 / 70$ & 正常 & I & $0 \%:$ & \\
\hline 33 & S.S. & $|\hat{\delta}| 19$ & -38 & 5.0 & +12.4 & 8.3 & +1.1 & $164 / 90$ & 正常 & I & $2.5 \%: \mathrm{R}_{3}$ & \\
\hline & 平 均 & 值 & -54 & 7.2 & +6.9 & 7.5 & +1.7 & & & & & \\
\hline
\end{tabular}




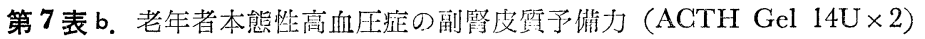

\begin{tabular}{|c|c|c|c|c|c|c|c|c|c|c|c|c|}
\hline \multirow{2}{*}{\multicolumn{2}{|c|}{ 症 例 }} & \multirow[b]{2}{*}{ 性 } & \multirow{2}{*}{$\mid \begin{array}{c}\text { 好酸球 } \\
\text { 減少雀 } \\
(\%)\end{array}$} & \multicolumn{2}{|c|}{$\begin{array}{l}\text { 総 } 17 \mathrm{OHCS} \\
(\mathrm{mg} / \text { /日) }\end{array}$} & \multicolumn{2}{|c|}{$\begin{array}{l}\text { 総 } 17 \mathrm{KS} \\
(\mathrm{mg} / 日)\end{array}$} & \multicolumn{2}{|r|}{ 監 } & 床 & 所 & 見 \\
\hline & & & & \begin{tabular}{|c|}
1 日 \\
排泄 \\
量
\end{tabular} & $\begin{array}{l}\mathrm{ACTH} \\
\text { による } \\
\text { 变動值 }\end{array}$ & $\left|\begin{array}{c}1 \\
\text { 日 } \\
\text { 排泄 } \\
\text { 量 }\end{array}\right|$ & $\begin{array}{l}\mathrm{ACTH} \\
\text { による } \\
\text { 変動值 } \\
\end{array}$ & $\frac{\text { 血 压 }}{(\mathrm{mm} H \mathrm{Hg})}$ & $\begin{array}{l}\text { 心電畄 } \\
\text { 所 見 }\end{array}$ & $\begin{array}{c}\text { 腿底 } \\
\text { 所睍 } \\
\text { (K.W.) }\end{array}$ & $\left(\begin{array}{c}1 / 10 \text { 機能 } \\
\text { BSP 及びコ } \\
\text { バルト反応 }\end{array}\right)$ & 其 の他 \\
\hline 1 & M.T. & $|\hat{o}| 59$ & | -80 & $|7.8|$ & +14.2 & $|7.3|$ & +1.1 & $220 / 110^{\prime}$ & $\mathrm{ST}_{\text {II III 低下 }}$ & II & $7.5 \%: \mathbf{R}_{4}$ & \\
\hline 2 & A.S. & \begin{tabular}{|l|l} 
今ิ 70 \\
\end{tabular} & -31 & 9.3 & -1.7 & 15.3 & -4.1 & $210 / 130$ & 正 常 & UII & $5 \%: \mathbf{R}_{4}$ & \\
\hline 3 & S.U. & 우 63 & -17 & 2.8 & +9.3 & 3.5 & +5.6 & $150 / 80$ & 正 常 & 䜣 & & \\
\hline 4 & S.H. & $\begin{array}{lll}\hat{\jmath} & 61\end{array}$ & -8 & 10.4 & +16.6 & 2.3 & +8.2 & $162 / 94$ & 正 掌 & II & $10 \%: \mathbf{R}_{2(3)}$ & \\
\hline 5 & $\mathrm{Y} . \mathrm{U}$. & 今ิ 65 & +5 & 8.6 & +7.6 & 8.0 & +3.0 & $174 / 80$ & 期外収縮 & II & $5 \%: \mathrm{R}_{5}$ & \\
\hline 6 & Y.I. & 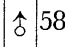 & -96 & 6.2 & +13.9 & 7.2 & +3.7 & $174 / 90$ & 正 常 & II & $7.5 \%:$ & 時飞沓蛋白(十) \\
\hline 7 & S.Y. & 今 56 & -88 & 12.1 & +7.3 & 11.0 & +2.4 & $168 / 90$ & 正 常 & III. & $5 \%: \mathrm{R}_{2(4)}$ & 尿蛋白（土） \\
\hline 8 & H.Y. & 个 57 & -65 & 3.1 & +5.2 & 5.6 & +0.6 & $190 / 120$ & ST I I 低下 & III & $2.5 \%: \mathrm{R}_{3}$ & 時に尿蛋白（土） \\
\hline 9 & T.Y. & 우 55 & -38 & 10.4 & +1.5 & 2.1 & +0.6 & $170 / 110$ & ST $T_{\text {I I 低下 }}$ & 伹 & $5 \%:$ & 眼底出血 \\
\hline 10 & G.D. & 令 58 & -68 & 8.1 & +2.3 & 3.7 & -1.2 & $152 / 86$ & $S T_{\text {I I 低下 }}$ & II & $10 \%: \mathrm{R}_{4}$ & 時に尿蛋白 $( \pm)$ \\
\hline 11 & M.H. & 令 55 & -27 & 11.0 & +8.6 & 11.5 & +0.2 & $210 / 110$ & ST II II 低下 & III & $7.5 \%:$ & 脳出血 \\
\hline 12 & M.M. & $\hat{0} 60$ & -37 & 18.0 & +4.6 & 5.3 & +2.2 & $220 / 100$ & $\mathrm{ST}_{\mathrm{I} \text { II 低下 }}$ & III & $5 \%: \mathrm{R}_{3}$ & \\
\hline 13 & $\mathrm{~S} . \mathrm{K}$. & 今ิ 58 & -52 & 10.9 & +9.1 & 9.3 & +4.8 & $200 / 110$ & 正 常 & III & $5 \%: \mathrm{R}_{3(4)}$ & \\
\hline 14 & $\mathrm{~T} . \mathrm{Y}$. & 968 & -35 & 4.5 & +8.8 & 8.9 & +0.6 & $174 / 102$ & 期外収縮 & II & $10 \%:$ & 時に尿蛋白 (土) \\
\hline 15 & $\mathrm{~T} . \mathrm{H}$. & if 70 & -38 & 2.3 & +4.1 & 1.8 & +1.0 & $170 / 90$ & $\mathrm{ST}_{\text {I I 低下 }}$ & II & $2.5 \%:$ & 尿蛋白(土） \\
\hline 16 & $\mathrm{~T} . \mathrm{Y}$. & $\hat{o} 58$ & $\begin{array}{ll}3 & -89\end{array}$ & 8.2 & +19.8 & 5.1 & +4.2 & $200 / 110$ & $S T_{\text {I II 低下 }}$ & III & $2.5 \%: \mathrm{R}_{3(4)}$ & 腿底出血 \\
\hline 17 & H.N. & i: 64 & -35 & 12.8 & +0.1 & 5.0 & +4.5 & $180 / 100$ & $S T_{\text {II II 低下 }}$ & III & $7.5 \%: \mathrm{R}_{2}$ & \\
\hline 18 & M.T. & 우 72 & -78 & 8.3 & +7.2 & 5.3 & +8.8 & $164 / 84$ & 期外収縮 & II & 0\%: & \\
\hline 19 & $\mathrm{~K} . \mathrm{K}$. & 우 64 & -25 & 6.8 & -0.5 & 5.0 & -1.0 & $220 / 120$ & $\mathrm{STV}_{56}$ 低下 & Hi & $7.5 \%:$ & 眼底出血 \\
\hline 20 & K.M. & 今 62 & -22 & 2.2 & +12.0 & 3.8 & +0.1 & $164 / 90$ & QRS 延長 & II & $5 \%: \mathrm{R}_{4}$ & 心臓抑膜症 \\
\hline 21 & H.M. & 우 59 & -70 & 5.0 & +7.2 & 7.1 & -0.1 & $164 / 70$ & 低電位差 & II & $7.5 \%:$ & \\
\hline 22 & M.H. & 우 57 & -68 & 5.9 & +18.5 & 7.2 & +5.0 & $164 / 100$ & 正＼cjkstart常 & II & & \\
\hline 23 & $\mathrm{~K} . \mathrm{N}$. & 令 68 & --6 & 8.8 & -0.7 & 4.3 & +1.8 & $194 / 110$ & 心房細動 & III & $5 \%: \mathrm{R}_{5}$ & 这出血 \\
\hline 24 & Y. I . & 㑒 60 & -52 & 9.0 & +9.0 & 7.5 & +1.5 & $174 / 96$ & 正 常 & II. & $2.5 \%:$ & \\
\hline 25 & S.O. & 今 58 & -60 & 14.1 & +15.8 & 12.5 & +7.2 & $160 / 80$ & 正 常 & II & $0 \%: \mathrm{R}_{2(3)}$ & \\
\hline 26 & T.M. & +9 67 & -41 & 5.6 & +18.1 & 3.5 & -0.3 & $200 / 110$ & 期外収縮 & II & $5 \%: \mathrm{R}_{3}$ & 時に层蛋白 $( \pm)$ \\
\hline 27 & $\mathrm{~K} . \mathrm{Y} \cdot$ & 今ิ 58 & -30 & 6.8 & +3.2 & 4.2 & +1.3 & $170 / 90$ & 正 常 & II & $0 \%:$ & \\
\hline & 平 均 & 值 & -46 & 8.1 & +8.2 & 6.4 & +2.3 & & & & & \\
\hline
\end{tabular}

健康人に於ては両者の間にかなりの相関がみられ本態性高血圧者に於ても若年者は老年者に榆バやや相関が あるように思われる。

\section{第 4 項 ACTH 貿荷による尿中総 $17 \mathrm{OHCS}$ の変動推移}

ACTH 負荷前日より負荷当日及び負荷翌日と連続 3 日間の尿中総 $17 \mathrm{OHCS}$ 值測定によりその变陲推移

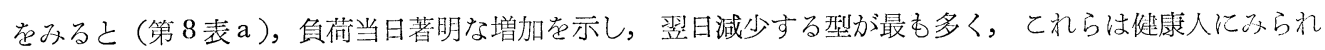
る型として正常反応型とした。猶その外負荷当日の増加少く或はむしろ減少を示し，翌日遅れて增加与る か或は引続き減少する型が数例あり，てれらは反応の遅延乃至は異常によるあのとして異常反応型とし前者 と区別した，異常反応型は特に老年高血圧者で多くみられた。

\section{第 5 項 其の他疾患者}

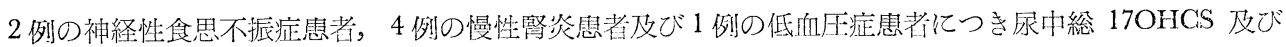

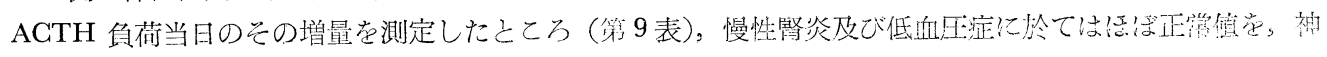


第4:図 $\mathrm{ACTH}$ 負荷による $17 \mathrm{OHCS}$ 变動と好酸球減少率の関係

(若年者)

17 OHCS 变動値 $(\mathrm{mg} / \mathrm{g}) \rightarrow$

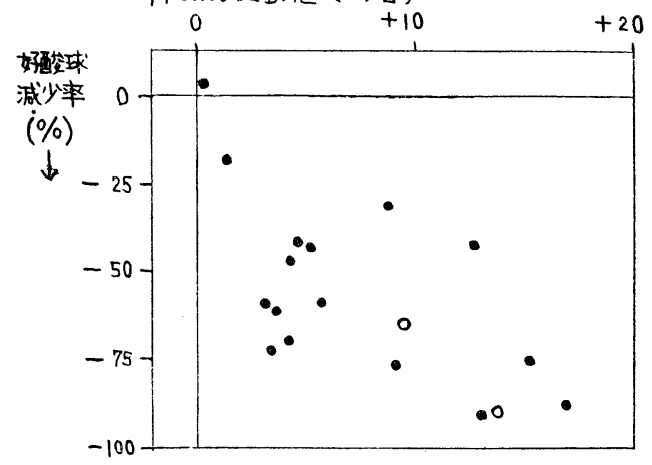

(老年者)

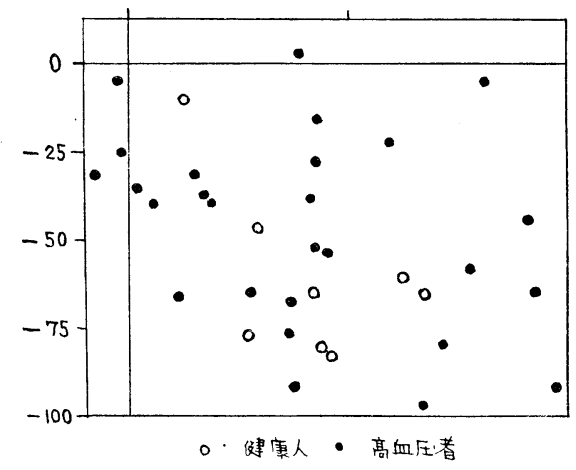

第 8 表 $\mathrm{ACTH}$ 負荷時の $17 \mathrm{OHCS}$ 及び $17 \mathrm{KS}$ 値変動推移

\section{a. 170HCS}

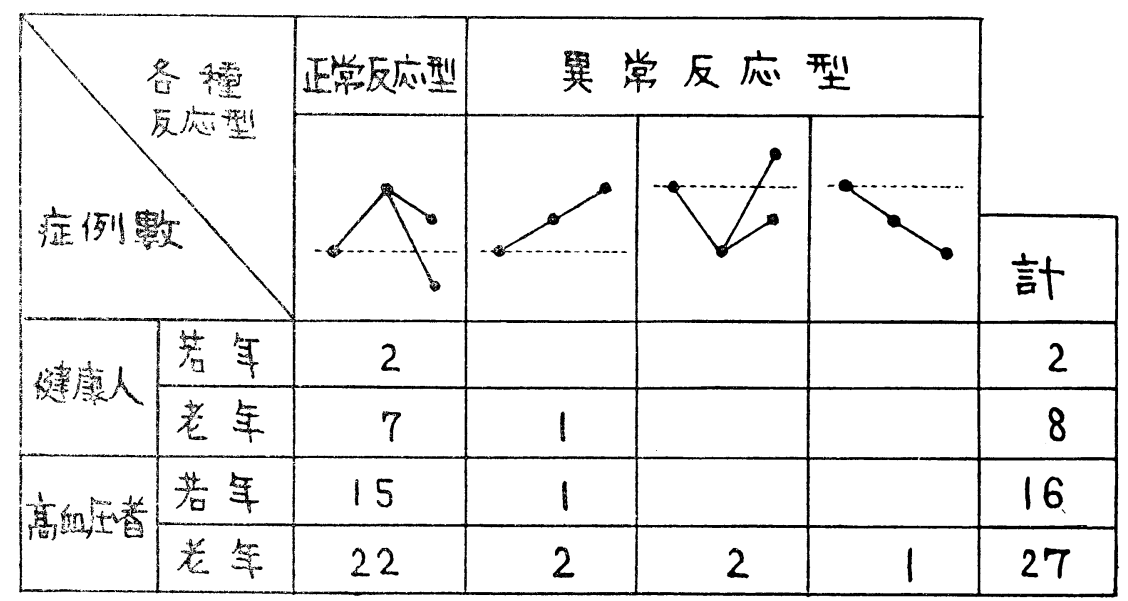

b. $17 \mathrm{ks}$

\begin{tabular}{|c|c|c|c|c|c|c|}
\hline \multirow{2}{*}{ 健瘭人 } & 苔年 & 10 & & & & 10 \\
\hline & 花年 & 6 & 2 & & & 8 \\
\hline \multirow{2}{*}{ 裏血压晢 } & 著些 & 27 & 2 & 3 & 1 & 33 \\
\hline & 老等 & 21 & 1 & 2 & 3 & 27 \\
\hline
\end{tabular}


第 9 表 其の他疾患者の副腎皮質子供力 $($ ACTH Gel $14 \mathrm{U} \times 2)$

\begin{tabular}{|c|c|c|c|c|c|c|c|c|c|c|c|}
\hline \multirow[b]{2}{*}{ 疾患名 } & \multirow{2}{*}{\multicolumn{2}{|c|}{ 症 例 }} & \multirow[b]{2}{*}{ 性 } & \multirow[b]{2}{*}{ 年令 } & \multirow{2}{*}{$\begin{array}{c}\text { 好酸球 } \\
\text { 減少率 } \\
(\%)\end{array}$} & \multicolumn{2}{|c|}{$\begin{array}{l}\text { 総 17OHCS } \\
(\mathrm{mg} / \text { /日) }\end{array}$} & \multicolumn{2}{|c|}{$\begin{array}{l}\text { 総 } 17 \mathrm{KS} \\
(\mathrm{mg} / \mathrm{\theta})\end{array}$} & \multicolumn{2}{|c|}{ 臨 床 所 見 } \\
\hline & & & & & & $\begin{array}{l}1 \text { 日排 } \\
\text { 泄量 }\end{array}$ & $\begin{array}{l}\text { ACTH } \\
\text { による } \\
\text { 変動值 }\end{array}$ & $\begin{array}{c}1 \text { 日排 } \\
\text { 泄 量 }\end{array}$ & $\begin{array}{l}\text { ACTH } \\
\text { にょる } \\
\text { 変動値 }\end{array}$ & 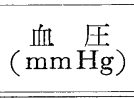 & 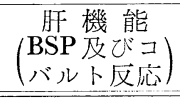 \\
\hline \multirow{3}{*}{$\begin{array}{l}\text { 神思 } \\
\text { 経不 } \\
\text { 性振 } \\
\text { 食症 }\end{array}$} & 1 & K.A. & 우 & 17 & -26 & 4.8 & +0.8 & 4.9 & +0.8 & $112 / 60$ & $5 \%: \mathrm{R}_{3}$ \\
\hline & 2 & $\mathrm{Y} . \mathrm{O}$. & $\hat{\jmath}$ & 30 & -29 & 5.2 & -2.1 & 2.6 & +1.6 & $124 / 62$ & $0 \%: \mathrm{R}_{3}$ \\
\hline & \multicolumn{3}{|c|}{ 平均 } & 值 & -27 & 5.0 & -0.7 & 3.8 & +1.2 & & \\
\hline \multirow{5}{*}{$\begin{array}{l}\text { 慢 } \\
\text { 性 } \\
\text { 腎 } \\
\text { 炎 }\end{array}$} & 1 & M.K. & 우 & 24 & -87 & 3.2 & +7.4 & 4.9 & +2.3 & $144 / 74$ & $5 \%: \mathrm{R}_{4}$ \\
\hline & 2 & N.H. & 우 & 21 & -100 & 5.8 & +11.7 & 6.9 & +1.6 & $136 / 70$ & 0\%: \\
\hline & 3 & $\mathrm{~K} . \mathrm{O}$. & $\hat{\jmath}$ & 27 & -73 & 7.2 & +3.3 & 6.8 & +0.4 & $160 / 80$ & $2.5 \%: \mathrm{R}_{5}$ \\
\hline & 4 & $\mathrm{~S} . \mathrm{Y} \cdot$ & $\hat{\delta}$ & 48 & -95 & 7.2 & +6.4 & 2.7 & +1.5 & $154 / 74$ & $10 \%:$ \\
\hline & \multicolumn{3}{|c|}{ 均 } & 值 & -89 & 5.9 & +7.2 & 5.3 & +1.3 & & \\
\hline \multirow{4}{*}{$\begin{array}{l}\text { 低 } \\
\text { 监 } \\
\text { 压 } \\
\text { 症 }\end{array}$} & 1 & A.N. & 우 & 21 & -16 & & & 5.2 & +4.3 & $96 / 60$ & $2.5 \%: \mathrm{R}_{4(4)}$ \\
\hline & 2 & Y.S. & 우 & 40 & +15 & & & 5.1 & +0.4 & $90 / 50$ & $5 \%:$ \\
\hline & 3 & $\mathrm{~T} . \mathrm{Y}$. & $\hat{\delta}$ & 38 & -52 & 4.4 & +3.4 & 3.9 & +0.3 & $96 / 40$ & \\
\hline & & 平 & & 査 & -18 & 4.4 & +3.4 & 4.7 & +1.7 & & \\
\hline
\end{tabular}

経性食思不症症に於ては ACTH 保街による增星に関して異常值を示した。

\section{第3 節 小 括}

木態性高血压者の㽷中総 $17 \mathrm{OHCS} 1$ 日排汧量は健康人とほぼ同值を示すが，ACTH 偩街による增量の 程度は健康人よりやや恶い．1 日排泄量及び増量に関して，健康人及び高血压者共若年老年者別の相違は特 にみられないが，男女別平均值に於ては女子は男子より低值を示した。 又 ACTH 傎荷による増量と好酸球 減少率との間には健康人及び若年高血压者に於てやや相関があるように思わせる。ACTH 負荷による総17

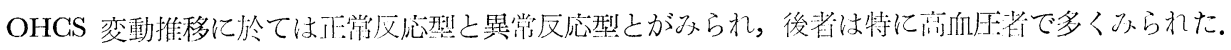

\section{第 5 章 尿中総 17KS について}

\section{第 1 節 序 言}

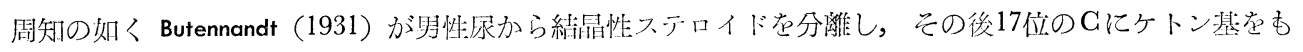

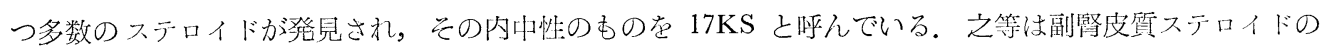
代㴬産物，一部 testosterone の代謝産物であり，從つて $17 \mathrm{KS}$ 測定は副䝳皮質や箤丸の機能検査に用いら れる．測定の原理は Zimmermann ${ }^{64)}$ が発見した呈色反応に基くあので，私は三毞变法を用いて実験を進めた。 Butt $^{12)}$ は 17KS 測定で有意なのは Addison 氏病と Simmonds 氏病の場命のみであると極言しているが。確に

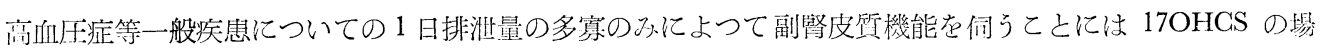

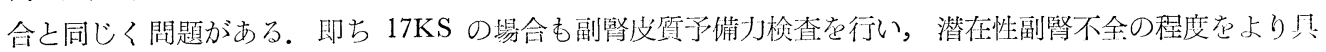

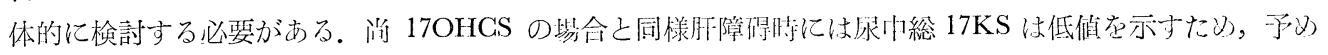
これらは除外した。

\section{第 2 節 実験成績}

第 1 項 健 康人

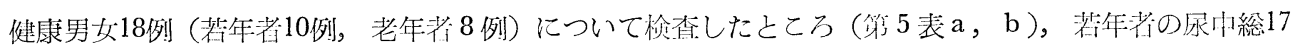
$\mathrm{KS}$ 值の平均は $7.0 \mathrm{mg} /$ 日， ACTH 負荷当日の增量平均は $+2.9 \mathrm{mg} /$ 日であつた. 老年者の尿中総 $17 \mathrm{KS}$ 傎

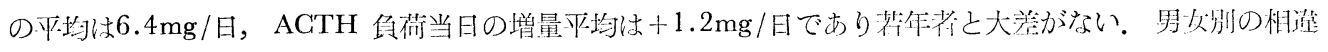


をみると (第 10 表), 男女各 9 例の総 $17 \mathrm{KS}$ 值の平均は，男子 $7.2 \mathrm{mg} /$ 日，女子 $6.2 \mathrm{mg} /$ 日とやや女子に低值 を示し，ACTH 負荷当日の増量平均も男子 $+2.7 \mathrm{mg} /$ 日，女子 $+1.6 \mathrm{mg} /$ 日と女子の增量は少ない，尚健康 人全例の尿中総 $17 \mathrm{KS}$ 值の平均は $6.7 \mathrm{mg} /$ 日, ACTH 負荷当日の增量平均は $+2.2 \mathrm{mg} /$ 日であつた.

\section{第 2 項 本態性高血圧者}

本態性高血圧者男女60例（若年高血圧者33例，老年高血圧者27例）について検查したところ（第 7 表 $a$ ， b )，萑年高血圧者の尿中総 $17 \mathrm{KS}$ 做の平均は $7.5 \mathrm{mg} /$ 日，ACTH 負荷当日の増量平均は $+1.7 \mathrm{mg} /$ 日であ 第10表 健康人及び高血压者の男女別尿中総 $17 \mathrm{KS}$ 值

\begin{tabular}{|c|c|c|c|c|c|c|c|}
\hline \multirow[b]{2}{*}{ 健康人 } & \multirow{2}{*}{$\begin{array}{c}\text { 性 } \\
\text { 定 } \\
\text { 우 }\end{array}$} & \multirow{2}{*}{$\begin{array}{c}\text { 例 } \\
9 \\
9\end{array}$} & \multirow{2}{*}{$\frac{\text { 数 }}{18}$} & \multicolumn{2}{|c|}{$\begin{array}{c}1 \text { 日排泄量可均 } \\
(\mathrm{mg} / \text { 日) }\end{array}$} & \multicolumn{2}{|c|}{$\begin{array}{c}\text { ACTH による増量平均 } \\
(\mathrm{mg} / \text { 日) }\end{array}$} \\
\hline & & & & $\begin{array}{l}7.2 \\
6.2\end{array}$ & 6.7 & $\begin{array}{l}+2.7 \\
+1.6\end{array}$ & +2.2 \\
\hline 高血压者 & $\begin{array}{l}\text { 令 } \\
\text { 우 }\end{array}$ & $\begin{array}{l}43 \\
17\end{array}$ & 60 & $\begin{array}{l}7.7 \\
5.2\end{array}$ & 7.0 & $\begin{array}{l}+2.0 \\
+1.9\end{array}$ & +2.0 \\
\hline
\end{tabular}

第5図 ACTH 負荷による $17 \mathrm{KS}$ 変動々 好酸球減少率の関係

\section{(若年荅)}

$17 \mathrm{KS}$ 变動値 $(\mathrm{mg} / \mathrm{g}) \rightarrow$

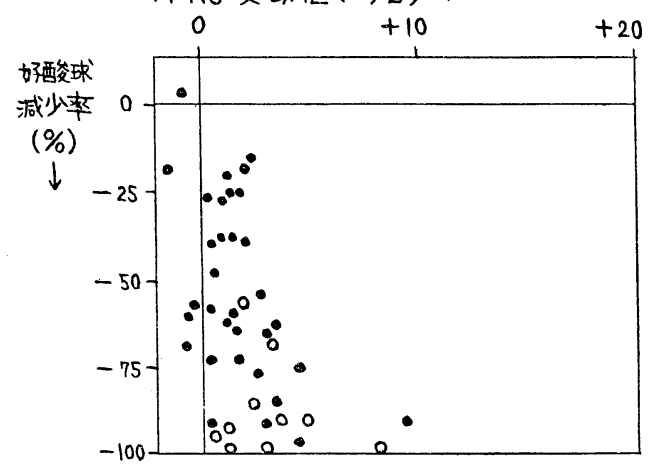

(老年者)

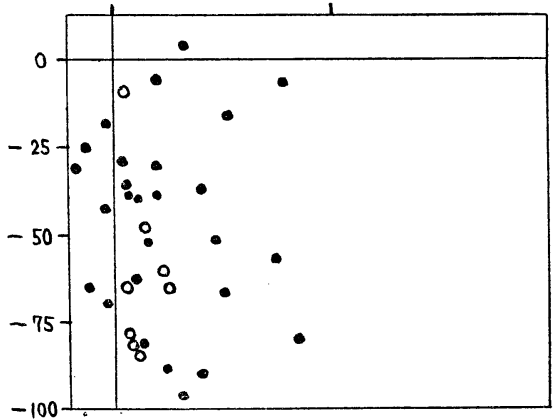

○・建康人・: 高血压者
第6図 尿中総 $17 \mathrm{OHCS}$ と総 $17 \mathrm{KS}$ 排泄值の関係 (若年者)

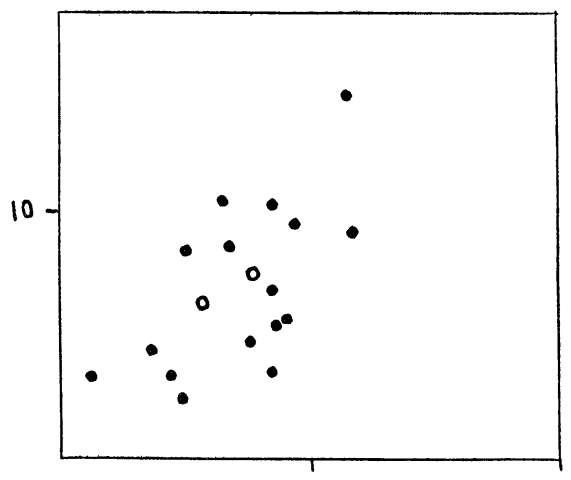

(老年者)

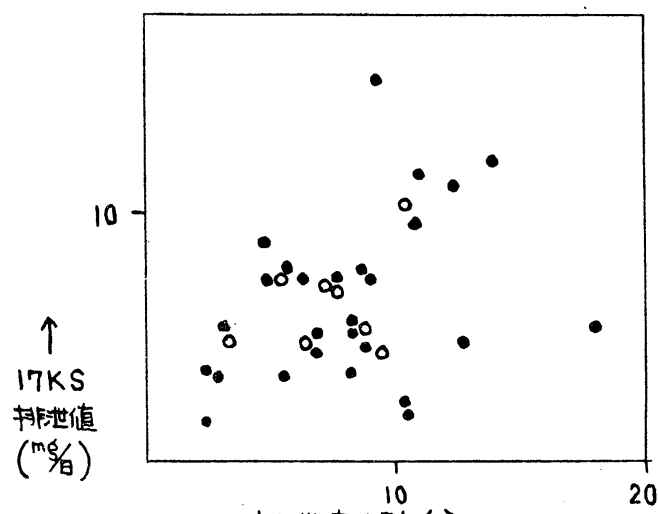

17 OHCS 排泄䛧 $(\mathrm{mg} / \mathrm{g}) \rightarrow$ ○：健康人・:高血压老 
つた. 老年高血圧者の尿中総 $17 \mathrm{KS}$ 值の平均は $6.4 \mathrm{mg} /$ 日。 ACTH 負荷当日の增量平均は $+2.3 \mathrm{mg} /$ 日之若 年高血圧者との間に有意の差はみられない，男女別の相違をみると(第 10 表), 男子 43 例，女子17例につい ての総 $17 \mathrm{KS}$ 值の平均は男子 $7.7 \mathrm{mg} /$ 日，女子 $5.2 \mathrm{mg} /$ 日之やや女子に低值を示すが, ACTH 負荷当日の増 量平均に於ては男子 $+2.0 \mathrm{mg} /$ 日, 女子 $+1.9 \mathrm{mg} /$ 日とほぼ同值である. 尚本態性高血圧者全例の尿中総 $17 \mathrm{KS}$ 值の平均は $7.0 \mathrm{mg} /$ 日, ACTH 負荷当日の増量平均は $+2.0 \mathrm{mg} /$ 日であつた.

第 3 項 ACTH 負荷による尿中総 $17 \mathrm{KS}$ の变動亡好酸球減少率との関係

ACTH 負荷当日の総 $17 \mathrm{KS}$ 増減量と好酸球減少率との関係を若年及び老年者別にみたが (第 5 図)，17 OHCS 亿較べて 17KS の変動量は少く，健康人及び高血圧者共好酸球減少率との間に一定の関係はみられ なかつた。

第4 項 ACTH 負荷による尿中総 17KS の変動推移

ACTH 負荷前日より負荷当日及び負荷翌日之連続 3 日間の沓中総 $17 \mathrm{KS}$ 值測定によりその変動推移をみ. ると（第 8 表 b )，17OHCS の場合と同じく正常反応型と異常反応型がみられ，異常反応型は特に高血圧者 で多くみられた。

第 5 項 尿中総 17KS と総 17OHCS との関係

健康人及び本態性高血圧者纪き，尿中総 $17 \mathrm{KS}$ 之総 $17 \mathrm{OHCS} 1$ 日排泄量の関係を若年者及び老年者別 にその分布図からみると(第6図)，健康人に於ては大体平行関係を認むる屯高血圧者については必ずしす 密接な相関関係がないように思われる。

\section{第 6 項 其の他疾患者}

2 例の 神経性食思不振症患者，4 例の 慢性腎炎愳者及び 3 例の 低血圧症㭧者につき尿中総 $17 \mathrm{KS}$ 及び ACTH 負荷当日の増量を測定したととろ (第 9 表)，慢性简炎及び低血圧症はほぼ正常值を，神経性食思不 振症は 1 日排泄量がやや低値を示した。

\section{第3節 小 括}

本態性高血圧者の尿中総 $17 \mathrm{KS} 1$ 日排泄量及び ACTH 負荷による増量の程度は健康人のそれとほぼ同 佔を示した. 又若年老年者別の相違も特にみられなかつた。男女別平均值に於ては 1 日排泄量及び増量共女 子は男子より一般に低値を示した。AGTH 負荷による增量と好酸球減少葆との間には特に相関はなく， ACTH 負荷による総 $17 \mathrm{KS}$ 恋動推移に於ては舅常反応型を高血圧者で多くみた. 又尿中総 $17 \mathrm{KS}$ と総17 OHCS 1 日排泄量の間には特に平行関係がない.

\section{第 6 章 尿中 $17 \mathrm{KS}$ 分劃について}

\section{第 1 節 序 言}

尿中総 $17 \mathrm{KS}$ 亿は副腎皮質のみならず睪丸より由来する testosterone の代謝尘物即ち androsterone も含 まれることは先に述べた，從つて本来の glucocorticoid 由来と考えられる 11-hydroxylated 17KS と androgen 由来のあのを分離測定する事は各ステロイド代謝研究上必要であり又臨床上の意義む大である。尿 中に排泄される主な 17KS は，androsterone (IV 分劃)， etiocholanolone ( V 分劃), dehydroisoandrosterone (III分劃), 11-hydroxyandrosterone（VI分劃），11-hydroxyetiocholanolone（汭分劃）であつて前二者

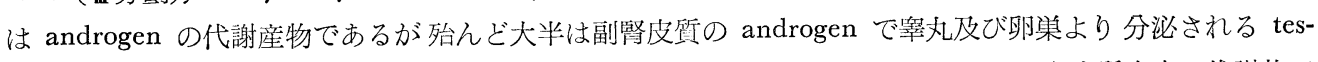
tosterone 代謝産物はわずかであると考元られる あるが androgenic な生物学的活性を有している。後二者は副腎皮質の glucocorticoid より由来するあの で cortison, hydrocortison 更にそれより変化した adrenosterone から生ずると考えそれているる6 ${ }^{465)}$. 近年 microscale chrouratography を利用して尿中 $17 \mathrm{KS}$ 分離測定法が相次で考案され，副婜皮質と $17 \mathrm{KS}$ との 関係をより具体的に追求できるようになつた。健康人及び各種疾㭧についての $17 \mathrm{KS}$ 分劃測定値は多数報 告されているが，私は更に AGTH 負荷前後の $17 \mathrm{KS}$ 分劃の変動を全例について観察し，副腎皮質予備力 の内容をより具体的に検討した. 


\section{第 2 節 実験成績}

第 1 項 健 康人

健康男女18例（若年者10例，老年者 8 例）について检査したところ（第11表 a，b)，若年者の尿中17KS 分劃の成績は，分劃1.1 12.0\%，平均7.1\%， IV + V 分劃 $27.4 \sim 57.7 \% ，$ 平均 $46.3 \% ， \mathrm{VI}+\mathrm{VI}$ 分劃21.8 $60.1 \%$ ，平均 $39.9 \%$ であり，老年者のそれは，分劃 $3.3 \sim 9.2 \% ，$ 平均 $6.4 \% ， \mathrm{IV}+\mathrm{V}$ 分劃 $24.0 \sim 60.5 \%$ ， 平均 $39.2 \%, \mathrm{~V}+\mathrm{VII}$ 分劃 32.6 66.6\%，平均 $49.2 \%$ であり若年者に較べて性腺系分劃（IV+V分劃）の減少

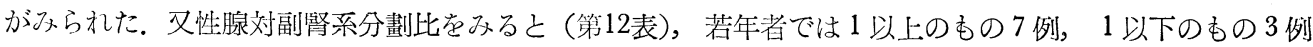
であつたが，老年者では 1 以上のもの 1 例，1 以下のもの 7 例と 1 以下のものが多い，更に男女別の相違を みると (第13表)，男女各 9 例の各分劃の平均值は，男子で分劃 $6.5 \% ， \mathrm{IV}+\mathrm{V}$ 分劃 $42.7 \% ， \mathrm{VI}+\mathrm{VII}$ 分劃 $46.6 \%$ ，女子では II 分劃 $7.0 \% ， \mathrm{~N}+\mathrm{V}$ 分劃 $43.6 \% ， \mathrm{~V}+\mathrm{VII}$ 分劃 $41.5 \%$ 之なり男女間の差は特に見当らなか

第11表 健康人の尿中 $17 \mathrm{~K} \mathrm{~S}$ 分劃及び ACTH 負荷によるその変動

a 。（若年健康人）

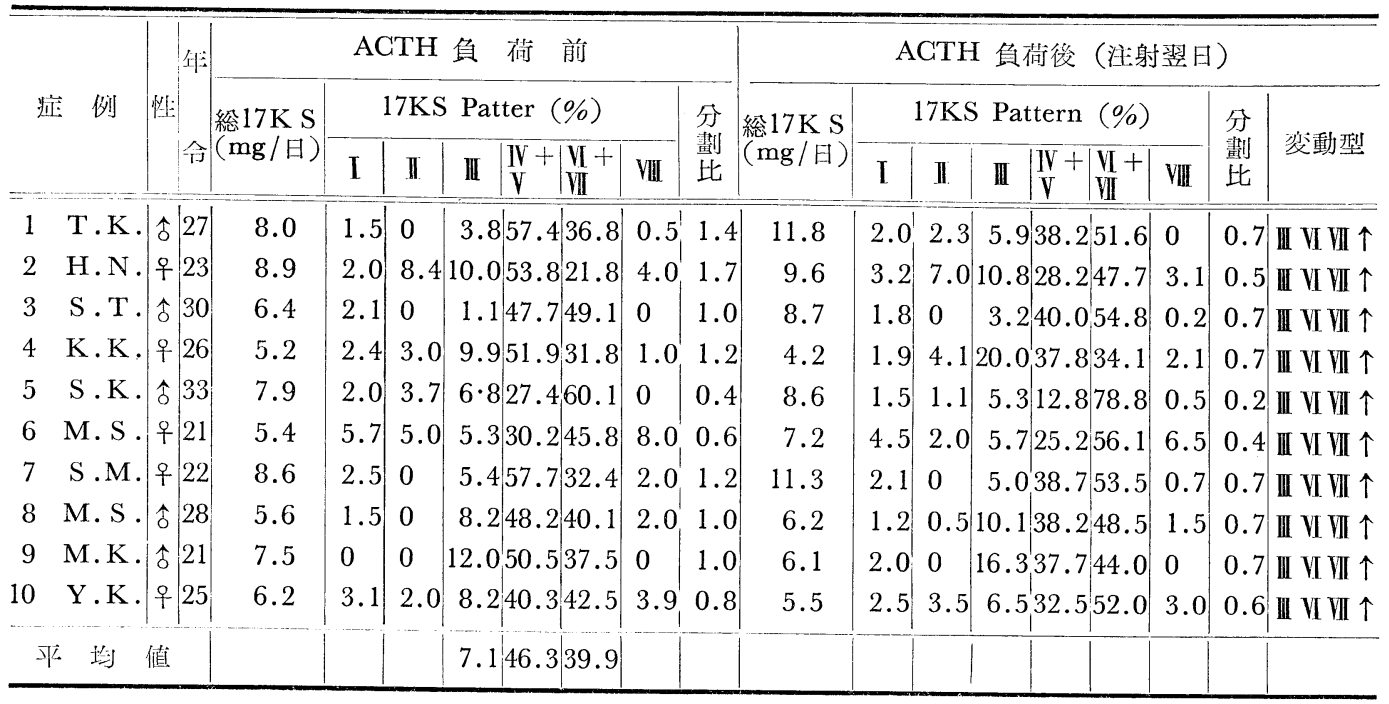

b.（老年健康人）

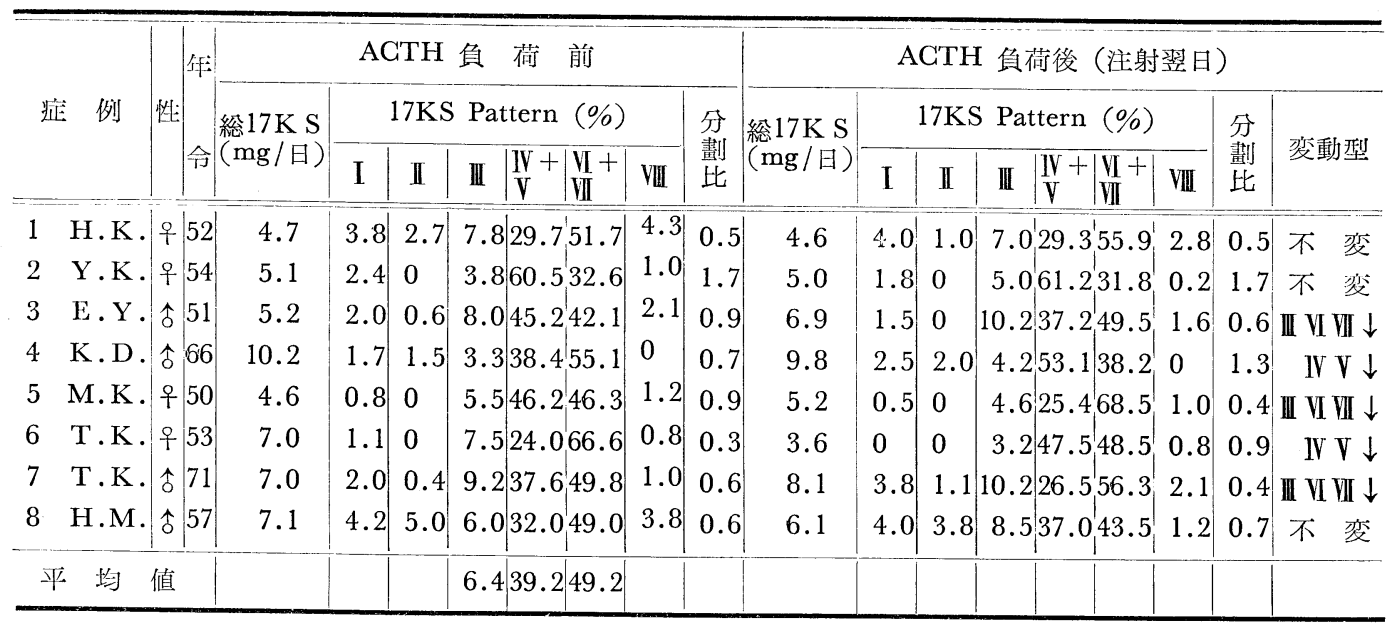


第12表 健康人及び高血圧者の性腺副腎系分劃比（例数）

\begin{tabular}{|c|c|c|c|}
\hline & & $\frac{\mathrm{I}+\mathrm{V}}{\mathrm{II}+\mathrm{VI}+\mathrm{WI}}>1$ & $\frac{\mathrm{IV}+\mathrm{V}}{\mathrm{II}+\mathrm{VI}+\mathrm{VII}}<1$ \\
\hline \multirow[b]{2}{*}{ 健康人 } & 若年者 & 7 & 3 \\
\hline & 老年者 & 1 & 7 \\
\hline \multirow[b]{2}{*}{ 高血圧者 } & 若年者 & 16 & 17 \\
\hline & 老年者 & 8 & 19 \\
\hline
\end{tabular}

つた. 次に ACTH 負荷前後の $17 \mathrm{KS}$ 分劃の 変動を比較すると，若年者に於ては全例副腎 系分劃の増加を示す III VI VII 个型を示し，老年 者に於てはこの型のものは 8 例中 3 例, 後は 性腺系分劃の増加する V V 个型が 2 例, 分劃 に変動のない不変型が 3 例と三型の変動を示 した.

\section{第 2 項 本態性高血圧者}

本態性高血圧者男女60例（若年 高血圧者33例, 老年高血圧者27例) について検查したところ（第14表 $a ， b)$ ，若年高血圧者の㽷中 17 KS 分劃の成績は， III 分劃 1.3 $10.8 \%$ ，平均 $6.0 \%, \mathrm{IV}+\mathrm{V}$ 分劃 $25.3 \sim 74.6 \%$, 平均 $47.6 \%$, V+

第14表a 若年者本態性高血圧症の尿中 $17 \mathrm{~K} \mathrm{~S}$ 分劃及び $\mathrm{ACTH}$ 負荷によるその変動

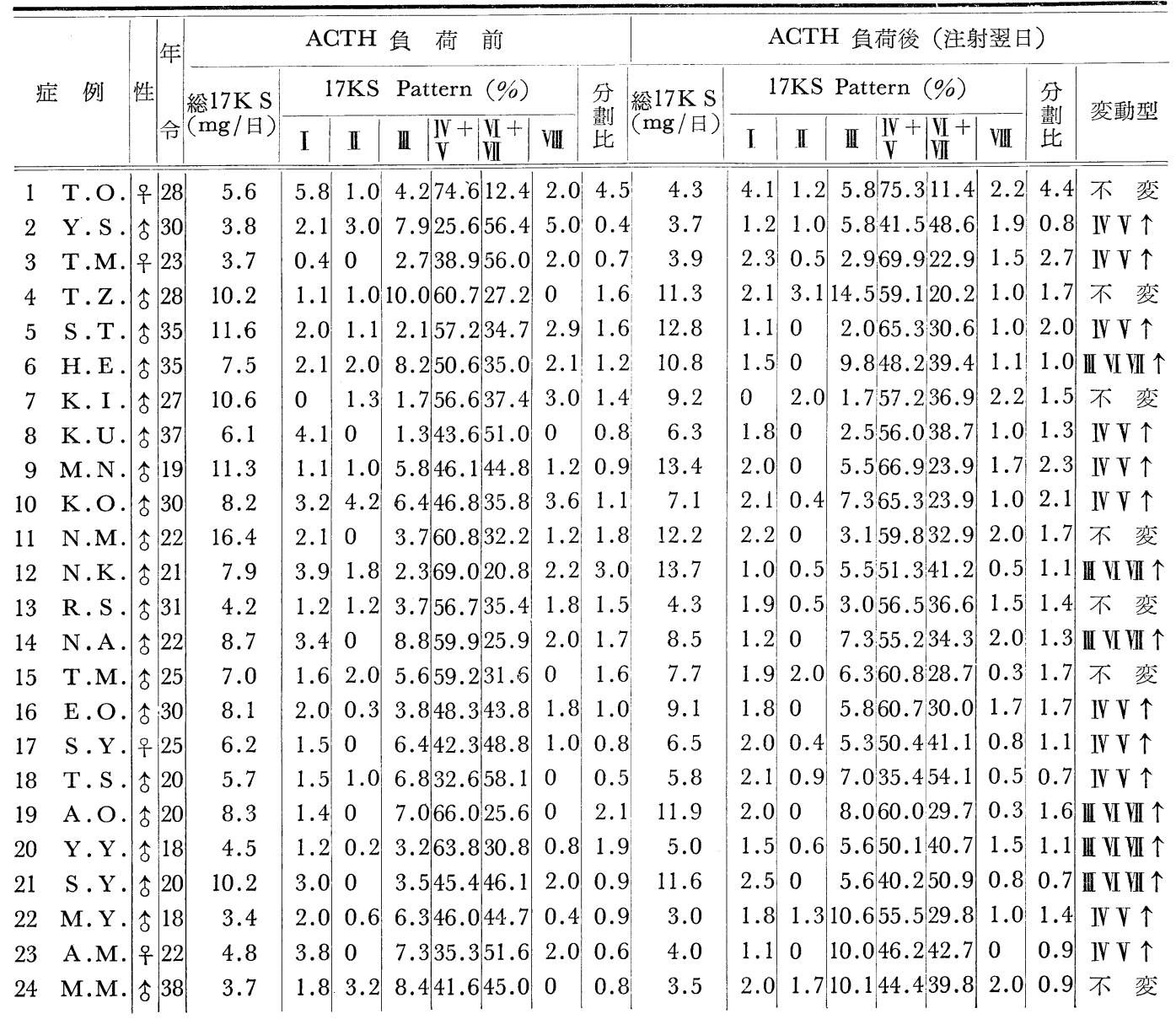




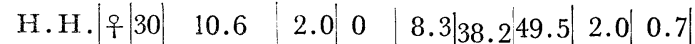
Y.K. +23 H.M. 18 M.O. $\hat{\delta} 26$ M.K. ? 36 K.S. . 19 S.Y. . 127 K.K. 全 28 S.S.昘 19
5.4

3.4

9.2

2.2

14.8

9.4

6.7

8.3

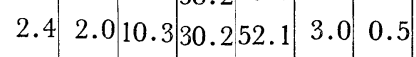

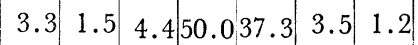

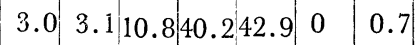

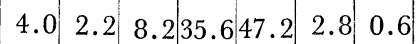

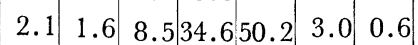
\begin{tabular}{l|l|l|l|l|l|l|l}
1.3 & 0 & 6.6 & 43.244 .9 & 4.0 & 0.8
\end{tabular} \begin{tabular}{ll|l|l|l|l|l|}
3.1 & 2.0 & 4.2 & 45.3 & 42.4 & 3.0 & 1.0
\end{tabular} \begin{tabular}{ll|l|l|l|l|l|l|l|}
4.8 & 2.3 & 9.8 & 25.3 & 53.1 & 4.7 & 0.4
\end{tabular}

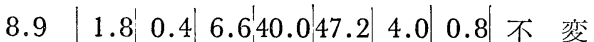
\begin{tabular}{ll|l|l|l|l|l|l|l}
4.2 & 1.8 & 0.6 & 7.5 & 40.347 .4 & 2.4 & 0.7 & $\mathrm{IV} \mathrm{V} \uparrow$
\end{tabular} \begin{tabular}{l|l|l|l|l|l|l|l|l}
3.0 & 2.6 & 0.5 & 10.848 .6 & 36.0 & 1.5 & 1.1 & 不変
\end{tabular} \begin{tabular}{l|l|l|l|l|l|l|l}
7.9 & 0.7 & 0 & 4.643 .351 .4 & 0 & 0.8 & 不変
\end{tabular} \begin{tabular}{|l|l|l|l|l|l|l|l|l|l|l|l|l|}
2.0 & 3.1 & 1.5 & 8.330 .054 .6 & 2.5 & 0.4 & II VI VII $\uparrow$
\end{tabular} \begin{tabular}{|l|l|l|l|l|l|l}
18.9 & 0.6 & 0 & 12.825 .760 .9 & 0 & 0.3 II II VII $\uparrow$
\end{tabular} \begin{tabular}{l|l|l|l|l|l|l|l}
8.5 & 1.0 & 0 & 10.136 .351 .5 & 1.1 & 0.6 & III VI VII $\uparrow$
\end{tabular} \begin{tabular}{l|l|l|l|l|l|l|l|l}
5.0 & 2.0 & 1.8 & 4.6 & 60.0 & 28.3 & 3.3 & 1.8 & $\mathrm{NV} \mathrm{V} \uparrow$
\end{tabular} \begin{tabular}{l|l|l|l|l|l|l|l|l|l|l|l|l|l|l|l|l}
7.5 & 2.2 & 1.0 & 12.3 & 40.041 .5 & 3.0 & 0.8 & $\mathrm{IV} \mathrm{V} \uparrow$
\end{tabular} 平均值 6.047 .641 .2

第14表 b 老年者本態性高血圧症の尿中 $17 \mathrm{~K} \mathrm{~S}$ 分劃及び ACTH 負荷によるその変動

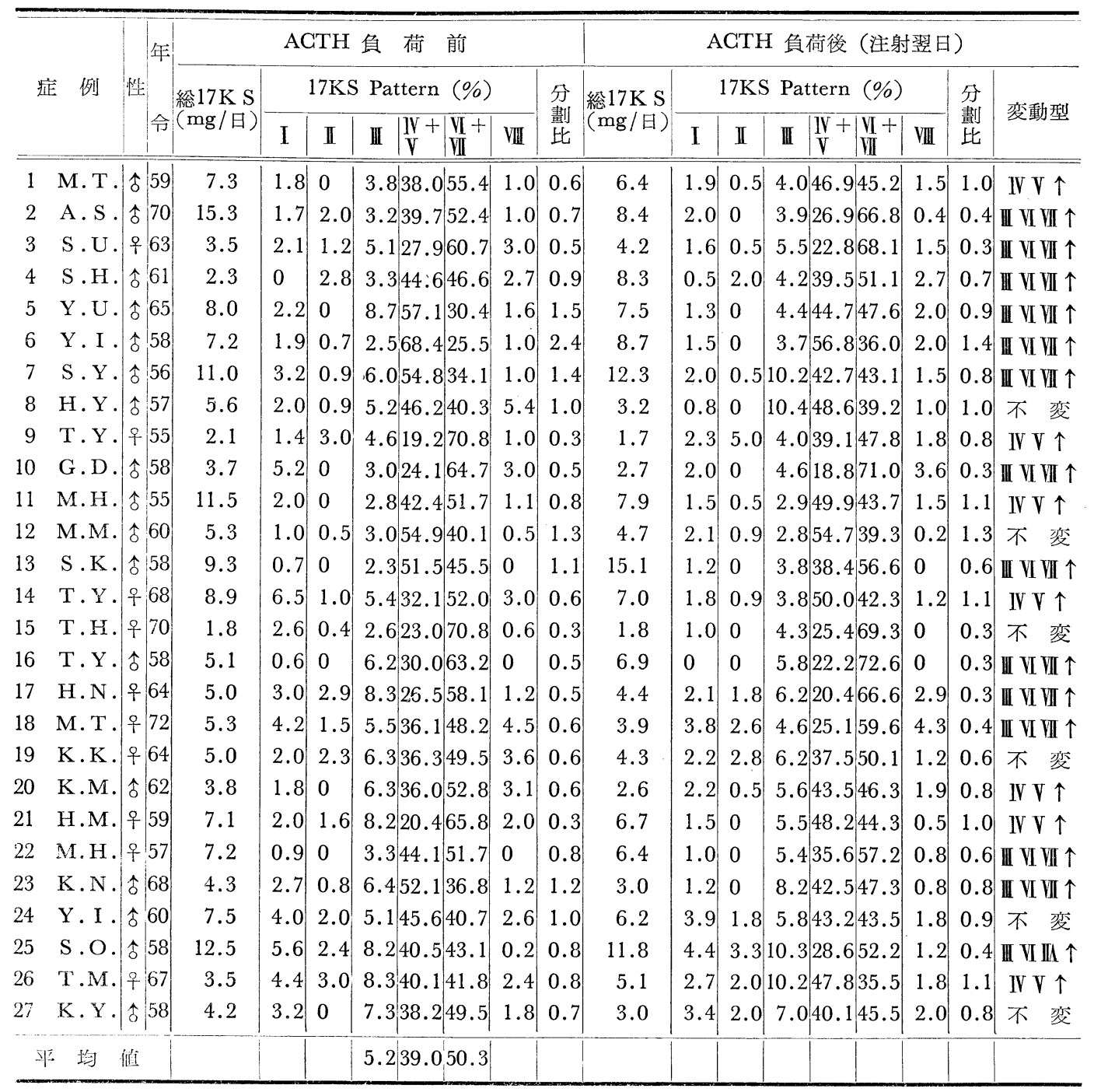


第7図 ACTH 負荷による $17 \mathrm{KS}$ 分劃の変動と好酸球減少率の関係

a. (若年者)

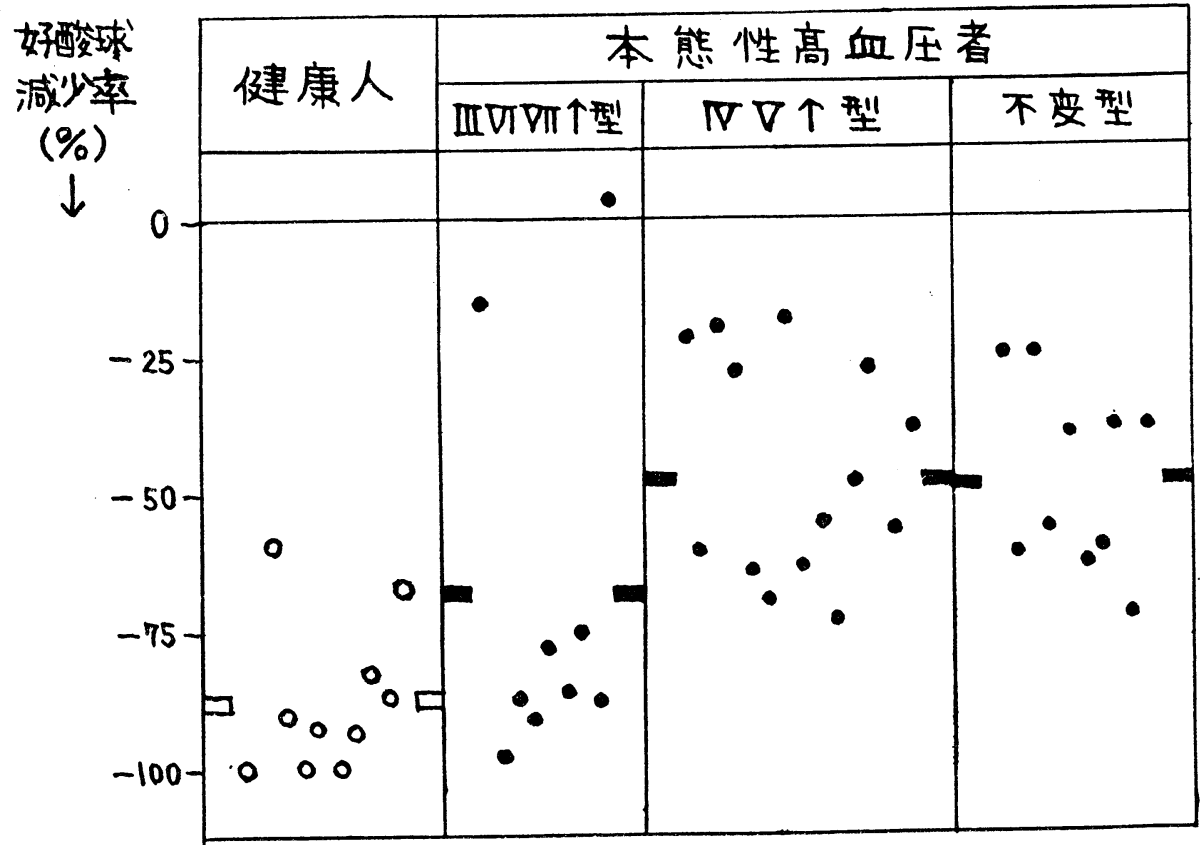

b. (老年者)

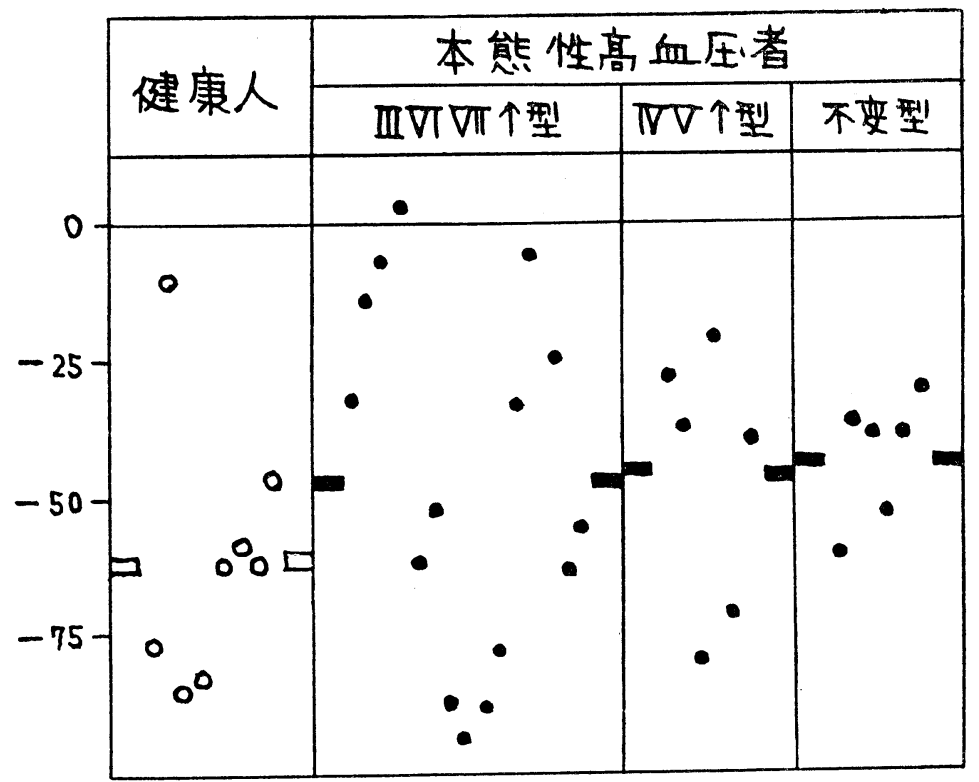

$\square$ : 健康人平均值, 淿: 高血圧者平均值 
VII分劃 $12.4 \sim 58.1 \%$ ，平均 $41.2 \%$ であり，老年高血圧者のそれは II 分劃 $2.5 \sim 8.7 \%$ ，平均 $5.2 \% ， \mathrm{IV}+\mathrm{V}$ 分 劃19.2 68.4\%，平均 $39.0 \% ， V I+V I I$ 分劃 25.5 73.2\%，平均 $50.3 \%$ であり若年高血圧者亿較へ性腺系分劃 （IV+V分劃）の減少がみられた，又性腺副堅系分劃比をみると（第 12 表），若年高血圧者では 1 以上のもの 16例，1 以下のもの17例とほぼ同数だが，老年高血圧者では 1 以上のあの 8 例，1 以下のあの 19 例と 1 以下 のむのが健康老年者同様多数みられた，更に男女別の相違をみる之（第13表），男子43例の各分劃の平均值 は，III分劃 $5.4 \% ， \mathrm{IV}+\mathrm{V}$ 分劃 $47.2 \% ， \mathrm{VI}+$ 而分劃 $42.4 \%$ あ゙あ，女子17例の之れは，III分劃 $6.2 \% ， \mathrm{IV}+\mathrm{V}$ 分劃 $34.9 \% ， \mathrm{VI}+\mathrm{VII}$ 分劃 $52.5 \%$ であり，IV+V分劃についてみると男子高血圧者の方が女子高血圧者より高 率を示した。次に ACTH 負荷前後の $17 \mathrm{KS}$ 分劃の変動を比較すると，若年高血圧者33例中 III IV VII $\uparrow$ 型は 9 例，IV V 个型は14例，不変型は10例であり，老年高血圧者 27 例では II VI VI 个型は14例，IV V 个型は 7 例， 不変型は 6 例と健康人同様三型の変動を示した.

第3 項 ACTH 負荷による尿中 $17 \mathrm{KS}$ 分劃の変動亡好酸球減少率との関係（特に若年高血圧者の場合）

若年高血圧者の好酸球減少率之 ACTH 負荷時の $17 \mathrm{KS}$ 分劃の三つの变動型之の 関係をみると（第 7 図 a ）ＩV V 个型14例之不変型10例の好酸球減少率平均は大体同程度で，それぞれ-48\%，-49\%であるが， III VI VII 个型 9 例では好酸球減少率が良好なすの多く, それらの平均值はー 69\% と健康人に近い值を示した。 尚老年高血圧者に於ては以上の如き関係は見当らなかつた（第 7 図 b ).

\section{第 4 項 其の他疾患者}

2 例の神経性食思不振症患者， 4 例の慢性腎炎患者及び 3 例の低血圧症患者につき尿中 $17 \mathrm{KS}$ 分劃及び AGTH 負荷によるその変動を観察したところ (第15表), 神経性食思不振症では健康人より IV + V 分劃がや や多く，AGTH 負荷による変動は 2 例共 III VI III 个型を示した，慢性腎炎の $17 \mathrm{KS}$ 分劃の Pattern 及び

第15表 其の他疾患者の尿中 $17 \mathrm{~K} \mathrm{~S}$ 分劃及び ACTH 負荷によるその変動 （神経性食思不振症）

\begin{tabular}{|c|c|c|c|c|c|c|c|c|c|c|c|c|c|c|c|c|c|}
\hline \multirow{3}{*}{ 症 例 } & \multirow{3}{*}{ 性 } & \multicolumn{7}{|c|}{ ACTH 負 荷 前 } & \multicolumn{9}{|c|}{$\mathrm{ACTH}$ 負荷後（注射翌日） } \\
\hline & & \multirow{2}{*}{$\begin{array}{l}\text { 総 } 17 \mathrm{~K} \mathrm{~S} \\
(\mathrm{mg} / \text { 日) }\end{array}$} & \multicolumn{5}{|c|}{ 17KS Pattern (\%) } & \multirow{2}{*}{$\begin{array}{l}\text { 分 } \\
\text { 劃 } \\
\text { 比 }\end{array}$} & \multirow{2}{*}{$\begin{array}{l}\text { 総17K S } \\
(\mathrm{mg} / \text { 日 })\end{array}$} & \multicolumn{6}{|c|}{$17 \mathrm{KS}$ Pattern (\%) } & \multirow{2}{*}{$\begin{array}{l}\text { 分 } \\
\text { 劃 } \\
\text { 比 }\end{array}$} & \multirow{2}{*}{ 変動型 } \\
\hline & & & I & II & III & $\mid \begin{array}{l}\mathrm{IV} \\
\mathrm{V}\end{array}$ & VIII & & & I & II & III & $\begin{array}{l}\mathrm{IV}+ \\
\mathrm{V}\end{array}$ & $\left|\begin{array}{l}\mathbf{V}+1 \\
\mathrm{VII}\end{array}\right|$ & VIII & & \\
\hline K. A. & 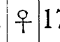 & 4.9 & 2.6 & 0 & 3.2 & 68.524 .3 & 1.5 & 2.5 & 4.6 & 1.3 & 0 & 4.4 & 41.6 & 52.7 & 0 & 0.7 & III VI VII $\uparrow$ \\
\hline $\mathrm{Y} . \mathrm{O}$ & $\mid \hat{o} 3$ & 2.6 & 1.0 & 0.9 & 4.0 & 61.231 .9 & 1.0 & 1.7 & 2.3 & 2.1 & 1.0 & 3.2 & 48.8 & 42.8 & 2.1 & 1.1 & III VI VII $\uparrow$ \\
\hline 平 & 值 & & & & 3.6 & 64.928 .1 & & & & & & & & & & & \\
\hline
\end{tabular}

（慢性䇛炎）

\begin{tabular}{|c|c|c|c|c|c|c|c|c|c|c|c|c|c|c|c|}
\hline 1 & M.K. & 우 24 & 4.9 & 3.8 & 2.2 & 10.836 .942 .5 & 3.8 & 0.7 & 5.6 & 3.2 & 3.1 & 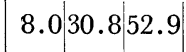 & 2.0 & 0.5 & III VI VII $\uparrow$ \\
\hline 2 & N.H. & 우 21 & 6.9 & 5.7 & 3.1 & \begin{tabular}{l|l|l|}
8.8 & 28.051 .9
\end{tabular} & 2.5 & 0.5 & 5.8 & 4.6 & 2.7 & \begin{tabular}{l|l|l|}
10.6 & 20.6 & 60.0
\end{tabular} & 1.5 & 0.3 & III VI VII $\uparrow$ \\
\hline 3 & K.O. & \begin{tabular}{|l|l|}
$\hat{0}$ & 27 \\
\end{tabular} & 6.8 & 1.0 & 0 & 7.054 .636 .8 & 0.6 & 1.3 & 5.5 & 1.7 & 0 & 5.652 .739 .0 & 1.0 & 1.2 & 不 変 \\
\hline 4 & S.Y. & $\mid$\begin{tabular}{l|l|}
$\mid \hat{\delta}$ & 48
\end{tabular} & 2.7 & 4.4 & 1.2 & 9.044 .438 .2 & 2.8 & 0.9 & 2.8 & 3.0 & 1.2 & \begin{tabular}{ll|l|l|}
7.5 & 40.1 & 47.4
\end{tabular} & 0.8 & 0.7 & III VI VII $\uparrow$ \\
\hline & 均 & 值 & & & & 8.941 .042 .4 & & & & & & & & & \\
\hline
\end{tabular}

（低血圧症）

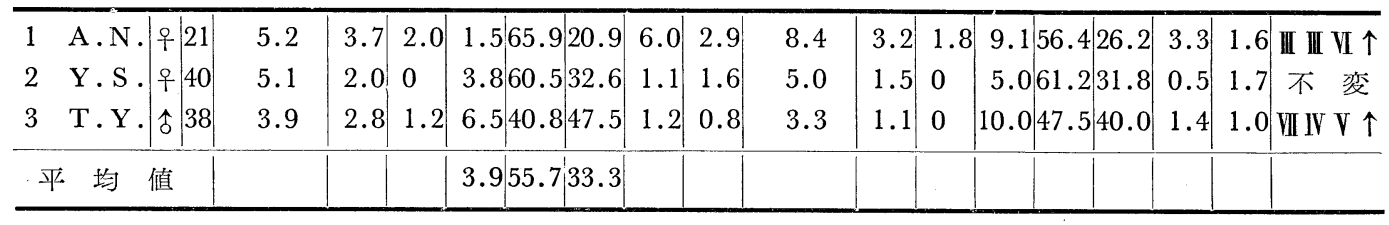


ACTH 負荷による変動は大体健康人のそれと似た值を示し，低血左症に於ては ACTH 負荷による変動型 もまちまちで一定の傾向はみられなかつた。

\section{第 3 節 小 括}

健康人及び本態性高血圧者につき尿中 $17 \mathrm{KS}$ 分劃を測定し，特に III 分劃，IV + V 分劃及びVI + VII 分劃の 各平均值及び性腺対副婜系分劃比を求めたところ，一般と老年者は若年者に較べ $N+V$ 分劃の減少があり， 分劃比では 1 以下のあのが多く特に健康人之高血圧者との差は認められなかつた。併し男女別平均值を求め ると，健康人ではその差はないが，高血圧者の場合IV+V分劃が特に男子で高率を示した。次に ACTH 負 荷による $17 \mathrm{KS}$ 分劃の変動をみると，健康人（特に若年者）はすべて III VI UII 型を示すが，高血圧者（若年 者老年者を含めて）は はII VI VIT 型の外に N V 个型及び不变型と三型の変動を示した. 又若年健康人及び高血 圧者の II VI VII $\uparrow$ 型の好酸球減少率は一般に良好であつた。

\section{第 7 章 総括並びに考按}

副腎皮質機能検査には所謂 Thorn’s Test 等間接的方法とホルモン自体或はその代謝産物を測定する直接 的方法とがあるが，corticoid の反応は非特異的であり更に血中 corticoid はその瞬間的濃度を表しているの みで，而も非常に不安定であるので測定操作も至難を極めるが，尿中代謝産物はその点比較的安定しており 特に尿中総 $17 \mathrm{OHCS}$ 及び総 $17 \mathrm{KS}$ の測定操作は簡単且精密化されており，更に $17 \mathrm{KS}$ のクロマトグラフ ィーによる分離定量す可能となつた現在，それら測定值の臨床的意義は益々大となつた。ただてれらステロ イド測定值は正常範囲が広い事，或は日差の甚しい事等から若干の特殊疾患即ち Addison 氏病，Cushing 氏 病，肝疾患等に於てのみ診断価值を有するともいわれ，真の副腎皮質機能診断にはこれら 1 日排泄量の外に Stress 負荷時の変動即ち副䴛皮質予備力を知ることが重要だといわれている.

$\mathrm{ACTH}$ 負荷試験に関しては, 1948年 Thorn ${ }^{58)}$ が垽謂 AGTH test を発表して以来その変法としてのAGTH 48時間法 ${ }^{59}$, 更には ACTH 点滴静注法 ${ }^{49}$ 等が引続き報告された。 乙れらにより予備力の内容がより具体的, 定量的に把握できるようになり，筋注による局所不活性化の難点も解決された．尚とれらは患者に負担が多 い久点があり，私はより簡便な Jenkins ${ }^{22}$ の ACTH Gel 筋注法を採用した。本法に於ける ACTH 負何量 は一般 stress 亿近似の最適な量でああり, てれ以上過量に投与された場合は軽度乃至中等度の皮質機能障碍 者に於てもステロイドの異常増加をきたし，本来の潜在性皮質不全の診断佂値が少くなるあのと考える.

好酸球減少率については, Fisher ${ }^{23)}$ は症例の $23.5 \%$ 亿空腹のみでー40\%の減少率をみることから副腎皮質機 能の指標としては価值がないと述へ，Thorn ${ }^{60)}$ 自身も stress による好酸球減少は副腎皮質分泌克進の指標と して直ちに信頼できないとしたが，生体側の条件或は ACTH 負荷方法に一考を加えれば臨床的には充分価 值のある皮質機能検查法と考えられる. 即ち私の行つた AGTH Gel 2 回筋注法に於ては他の response 即 ち 17OHCS，17KS 及び 17KS 分劃の変動の総てとは必ずしも相関を認めなかつたが，少くとも若年者に 関しては皮質活性の最大の指標と目される $17 \mathrm{OHCS}$ 変動量とかなりの相関を示し，更に $17 \mathrm{KS}$ 分劃変動型 に於ては健康人にみられる III VI UI $\uparrow$ 型て減少率良好な点から本法の特に若年者に対する診断価值はかなり大 きいと考えられる。 ACTH Gel 亿よる好酸球減少率の成績として, Jenkins ${ }^{329}$ は健康人の場合動摇範囲一66 〜-100\%，平均-88\%であるとし，私の若年健康人の成績と全く一致するが，老年者を含めた全例の平均 ではこれょり減少率がやや悪かつた。一方本態性高血圧症の好酸球減少率てついては，瀬戸岡 ${ }^{82}$ は 7 例の本 症患者につき動摇範团-54〜-81\%とい5成績を出し副腎皮質機能に異常ないあのと述べてい. 私の成績 では高血圧者は健康人に較へ減少率悪く本症の一部に副婜皮質機能異常を示す場合があるものと想像した。

17OHCS 測定は臨床的副腎皮質分泌の尺度として最屯適切且意義あるととは先に述べた. 尿中総 $17 \mathrm{OHCS}$ 值についての諸家の成績をみると，Reddy ${ }^{48}$ は健康人男女各 15 例の平均は男子 $5.8 \mathrm{mg} /$ 日，女子 $3.8 \mathrm{mg} /$ 日で あると述べ，鳥居 ${ }^{86)}$ は男子 $3.6 \sim 8.6 \mathrm{mg} /$ 日，女子5.6 6.4mg/日と報告している. 私の成績ではこれよりや や高值を示したが，熊谷 ${ }^{72}$ 等の平均 $10.3 \mathrm{mg} /$ 日には及ばなかつた。本態性高血圧者の尿中総 $17 \mathrm{OHCS}$ 值に ついては，三宅 ${ }^{74}$ は平均值に於て健康人之特に変りないと述へ，日品 ${ }^{699}$ は 6 例の本症患者について検查した 
ところ血漿中総 17OHCS 值は正常に保たれながら尿中総 17OHCS 排泄值が 5 例まで減少している事実を あげている．私の高血圧者についての成績では特に健康人との間に相違を認めなかつた。ACTH 負荷時の 17OHCS 変動に関しては，Jenkins ${ }^{322}$ は先ず健康人18例について ACTH 負荷当日の増量平均 $+19.6 \mathrm{mg} /$ 日, 動摇範囲 +4.9 ～+34.4mg/日であるとし，Addison 氏病等皮質機能低下症に於てはその值が低值を示すと述 べているが，私の成績では健康人と高血圧者との間に有意の差なく共にてれらよりやや低值を示した。 ACTH 負荷時の 17OHCS 変動推移については, Bayliss ${ }^{3}$ 等は健康人について AGTH 20 単位 8 時間点滴静 注, 20単位筋注及び ACTH Gel 20單位筋注の場合につきそれら血中濃度の变動推移を観察し, ACTH Gel 筋注の場合注射後 4 5 時間で血中濃度が最高に達し以後渐次低下するのをみている. 又 Christy ${ }^{13}$ 等は ACTH 25mg 点滴静注時の血中総 $17 \mathrm{OHCS}$ 濃度增加過程を各種疾患につき蛤討し，皮質機能低下症に於 てはその増加重く，充進症では増加が著明であると述べている。更に福井 ${ }^{700}$ ACTH-Z 負荷時に於ける尿 中総 $17 \mathrm{OHCS}$ の変動を48時間に亘つて観察し，注射後 4 8 時間目に著明に増加する正常型，反応の微弱 或は遅延を示す比較的不全型，無反応を示す絶体不全型と副腎皮質機能を三つに分類している. 私も ACTH 負荷による変動を 負荷前日から引続き 3 日間各 24 時間尿について 観察した結果，大多数は負荷当日著明に 17OHCS が増加する正常反応型を示すが，一部に注射当日 $17 \mathrm{OHCS}$ が減少するか或は増加の遅延する異常 反応型を主に高血圧者でみることができた。これらは副䝳皮質 activity の低下によるものと考えられる.

尿中総 $17 \mathrm{KS}$ 測定值については先の実験で総 17OHCS 值とは必ずしも平行関係を示さなかつたが，総 17OHCS 值が表現する副粲皮質 activity とは別の意味で分泌機能の目安となる点重要である. 尿中総 $17 \mathrm{KS}$ 值に関する報告は誠に多く，健康人について Keinesberg ${ }^{35}$ 注男子平均 $18.0 \mathrm{mg} /$ 日 $(11 \sim 27 \mathrm{mg} /$ 日)，女子平 均 $9.3 \mathrm{mg} /$ 日（7〜14 $\mathrm{mg} /$ 日）であるというが，私の成績では男女それぞれとれょりやや低值を示した。大

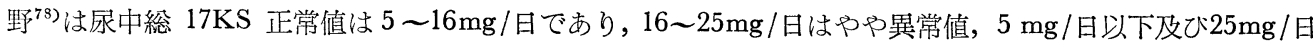
以上を病的值としているが，私の健康人の成績では $4.6 〜 10.2 \mathrm{mg} /$ 日と大体大野の成績と一致した，本態性

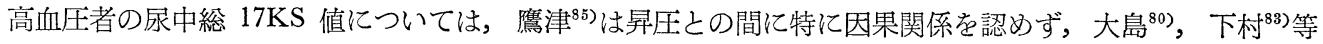
も本症に於ける尿中総 $17 \mathrm{KS}$ 值は正常範囲にあると述へている. 又幸田 ${ }^{71)}, \mathrm{Bruger}^{10)}$ 等はその低值を報告し ている。私の成績では健康人との間に特に相違を認めなかつた。 ACTH 負荷時の尿中総 $17 \mathrm{KS}$ 変動に関し ては，Jenkins ${ }^{329}$ は健康人18例につき ACTH 負荷当日の 増量平均 $+6.1 \mathrm{mg} /$ 日，動摇範囲 $0 \sim+19 \mathrm{mg} /$ 日之 しているが，私の成績では健康人及び高血圧者の間に特に有意の差なくてれらょりやや低值を示した。 ACTH 負荷時の $17 \mathrm{KS}$ 変動推移についても同様観察したが正常反応型の外に異常反応型を高血圧者で数例 認めた。乙れらは副腎皮質 activity の低下によるむのと考える。

副算皮質の glococorticoid activity の最も適切な尺度と考えられる 17OHCS と同時に 17KS 特にそれ を構成する各分劃の意義について考察することは副腎皮質ホルモン生合成及び代謝の様相を知る上に必要且 有意義なととと考える．先ず分劃を占める dehydroisoandrosterone は副腎皮質固有の 17KS であると考 えられているが，その precursor については未だ不明で副粲癌腫で著明に増加するととが知られており， Lieberman ${ }^{40)}$ は本物質の precursor は副腎皮質ホルモン生合成途上の中間代謝産物であろうと述べている. 次にN 分劃を占わる androsterone は adrenal hyperplasia 亿於て著明な増加のみられる場合があり ${ }^{37) ， 乙 ~}$ の際のホルモン代謝障碍機構について Jailer ${ }^{31}$ 等は副腎皮質ホルモン生合成途上における enzymatic defect

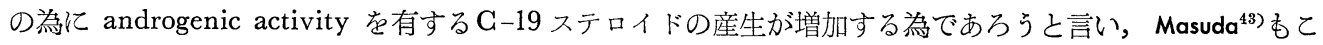
れと同様の見解を示している. 又VIVII分劃を占める11-oxy-17KS については，Burstein ${ }^{11}$ 訬 cortison 投与に 上り尿中に etiocholanolone 或は androsterone の排泄のないととから, 又 Masuda ${ }^{43}$ は健康人と congenital adrenal hyperplasia についての尿中 17KS の詳細な分析から，11-oxy-17KS の precursor としての corticoid はいづれも G-11，17，20 位に酸素を有するステロイドであり，逆に言えば 11-oxy-17KS は glucocorticoid 由来の副腎皮斦固有の分劃だと述べいる，健康人の尿中 $17 \mathrm{KS}$ 分劃測定值については，我国で 屯大野 ${ }^{79)}$ ，安達 ${ }^{66)}$ ，日犆 ${ }^{68}$ ，與津 ${ }^{77}$ 等の報告があり，大野は健康男子の平均值は III 分劃 $9.2 \% ， \mathrm{IV}+\mathrm{V}$ 分劃 $43.6 \% ， \mathrm{VI}+\mathrm{VII}$ 分劃 $21.0 \%$ であり，健康女子の之れは任分劃 $7.7 \% ， \mathrm{IV}+\mathrm{V}$ 分劃 $38.6 \% ， \mathrm{VI}+\mathrm{VII}$ 分劃 $27.9 \%$ 
とし男女間の差を認めてないが私の成績も大体とれと一致した。17KS 分劃の Pattern について，Robinson ${ }^{50)}$ は健康人のそれは個人差が可成り強いとしてれを四型と分けており，鈴木 ${ }^{84}$ は総 $17 \mathrm{KS}$ の日内変動にも拘ら ず各個人に固有の $17 \mathrm{KS}$ 分劃の Pattern はほぼ一定に保持されていると述へ，更に赤須年)は男女性差によ る相違，去性，更年期障碍及び諸䓡㭧時に於ける 17KS 分劃の Pattern の变動について述へている。私も 健康人及び高血圧者につき二時期に亘つて $17 \mathrm{KS}$ 分劃を測定したが，その Pattern は大体恒常性を示すと とが分つた。本態性高血圧症の $17 \mathrm{KS}$ 分劃については, 興津 ${ }^{77}$ は各分劃の割合は健康人と大差なく血圧と

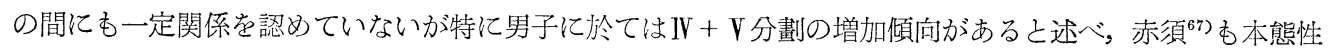
高血圧症や更年期障碍時に於ては副腎系分劃が比較的低いと述べている. 私の成績でも男子高血圧者の $1 V+$ V分劃はその平均值に於て増加を示すことから男子高血圧者に於ては皮質ホルモン相互間の不調和或は皮犋 内代謝異常があるあのと考えられる。次に $17 \mathrm{KS}$ を構成する各分劃の副㹂皮質内代謝過程を更に追求する 上に ACTH 負荷による $17 \mathrm{KS}$ 各分劃の変䃼を知るととは興味あるととと考光，私は予備力検查と平行し て ACTH Gel (14単位 $\times 2$ ) 負荷前後に於ける $17 \mathrm{KS}$ 分劃の変動につき観察した。ACTH 負荷による17

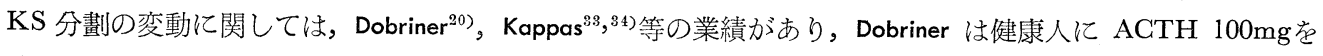
4 日間に亘り投与，各24時間尿につき連続その変動を観察しているが，てれら変動はACTH 大量長期投与 の結果みられる副腎皮質の過度の反応であり，皮質機能検查としてはより少量の ACTH で一般 stress 時に みられるような短時間内の変動につき検討しなければその意義は少ないと考える. ACTH Gel 負荷による 17KS 分劃の変動には III VIVI 个型，IV V 个型及び不変型があることは先に述べたが，てれら変動の意義につ いては未だ充分な説明ができない，即ち III VI VII 个型特にVI VII分劃の増加の理由については 11-oxy-17KS の precursor がC-11，17，20位に酸素を有する glucocorticoid であり，ACTH 負荷により glucocorticoid の 著明な増加をみることから容易に理解されるが，IV V 个型については ACTH 負荷による dehydroisoandrosterone の増加のために劃を占める androsterone が二次的に増えたあのか, Schneider ${ }^{55}$ のいう3 3 hydrogenase 等酵素系の障碍により 17OHCS の増加がありながら 11-oxy-17KS への転化が阻止されVIII 分劃の增加を示さないものかは不明である. Kappas ${ }^{33}$ あ ACTH 3 日間連続投与によりかかる症例を認妨て いるがそれに対する充分な説明はなされてない，又不変型については，鈴不 ${ }^{81}$ む Addison 氏病に際してかか る反応をみているが，乙れは ACTH 負荷により副婜皮質ホルモン産生分泌増加へのステロイドの動きが全 くない状態とみなされ，IV V 个型と共に副腎皮質反応性の異常によるものと考えた。

ACTH 負荷による尿中総 $17 \mathrm{OHCS}$ 及び総 $17 \mathrm{KS}$ の変動より副婜皮質機能（予備力）を伺わんとする試 みは古くから行われていたが，乙れらと ACTH 負荷による尿中 $17 \mathrm{KS}$ 分劃の前記三変動型との間に一定 の関係があるならば，それらの綜合により予備力の内容がより具体的に把握でき，更にはより正確な皮質機 能診断法として価值がでてくるあのと考光る。私は ACTH Gel 負荷時に於ける 17OHCS, 17KS 及び17 $\mathrm{KS}$ 分劃の 3 反応系にほぼ一定の関係があるととを知り，それより副腎皮質機能を三型に分類した。第 8 図 は以上 3 反応系の関係を理解し易いように分布図で表したもので, 健康人及び高血圧者を特に若年者, 老年 者別に表してある，先ず図のA区域内のものは ACTH 負荷により 17OHCS，17KS 共増加著明で 17KS 分劃変動に於ては総て III VI III 个型を示すむので，乙れらは副腎皮質 response 良好で而もとの代謝過程む正 常な点より皮質機能正常型と考えた。図のB区域内のむのは ACTH 負荷により 17OHCS, 17KS 共增牌 く $17 \mathrm{KS}$ 分劃变動に於ては大体不変型を示す場合で，乙れらは副粗皮質 activity の低下を示している点よ り皮質機能の比較的不全型と考元た。 又図のC区域内のむのは ACTH 負荷により 17OHCS の増加は正常 であるが 17KS の増加がわづかか或は逆にやや減少を示し 17KS 分劃変動に於ては総て V V 个型を示す場 合で，乙れらは副腎皮質内代謝異常を認めながら尚僅かながら response を示す点より前者同様皮質機能の 比輍的不全型と考えた。更に図の ABC 区域外のあのは ACTH 負荷により 17OHCS 及び 17KS の一方 或は両者共著明な诚少を示し $17 \mathrm{KS}$ 分劃変動は全く不定の場合で，乙れらは副腎皮質 response の面に於て あステロイド代謝の面に於ても全く異常であり非統一的反応を示す点より皮質機能不全型と考えた．以上の 如く副婜皮質機能を木態性高血圧者にみられる種々の反応型より正常型，比較的不全型及び不金型之三大別 
第 8 図 ACTH 負荷時に於ける $17 \mathrm{KS}$ 分劃変動型 と $17 \mathrm{OHCS}, 17 \mathrm{KS}$ 変動量との關係 （健康人及び高血圧者の場合）
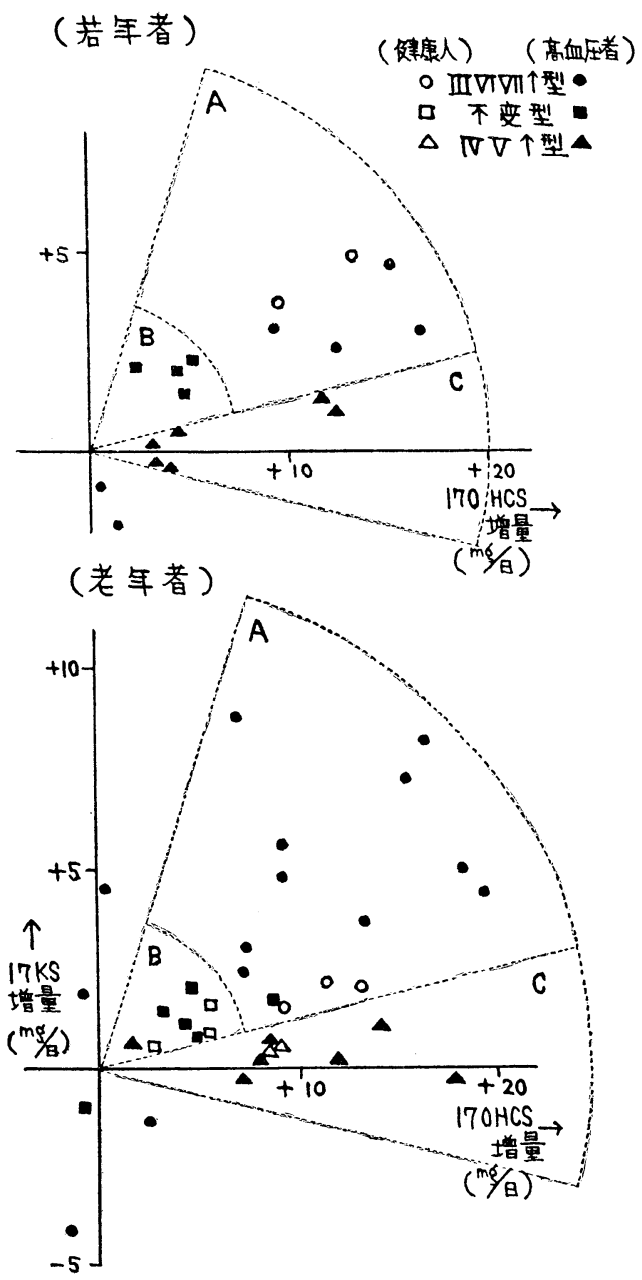

したが，所謂健康人の中にも，特に老年健康人に於 ては正常型を示すものの外飞比較的不全型を示す症 例を分布図でみることができる，老年者の副婜皮質 機能については，乙れまで全く正常であるとするあ $の^{25)}$ ，或は下垂体障碍により二次的皮質機能低下を

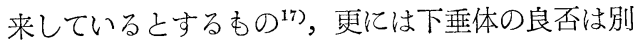
として Simmonds 氏病, Addison 氏病に近い軽度 皮質機能低下があると考えるむの 79 等その見解はま ちまちだが，私の成績では以上の如く老年者の中に 副腎皮質機能低下を示す場合がかなり多いことが分 つた.

尚 ACTH 負荷時にみられる前記 3 反応系の関係 を神経性食思不振症患者，慢性腎炎患者及び低血圧

第9図 $\mathrm{ACTH}$ 負荷時に於ける $17 \mathrm{KS}$ 分劃変動型 と $17 \mathrm{OHCS}, 17 \mathrm{KS}$ 変動量との関係 （其の他疾患者の場合）

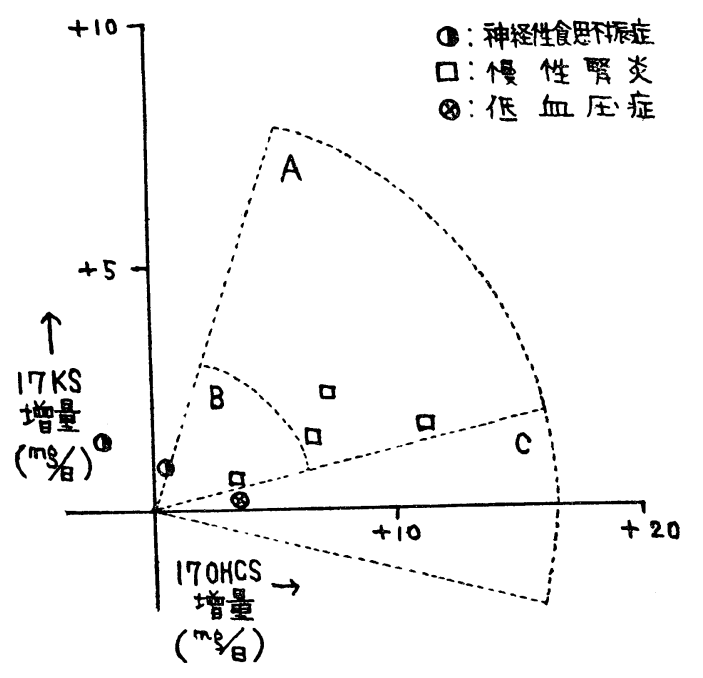

症患者に適用し，それらの副婜皮梊機能を分布図から伺うと（第 9 図），内分泌疾患と考えられる神経性食 思不振症では不全型を，慢性婜炎では大体正常型を示すととが分つた。

最後に本態性高血圧症を副腎皮啠機能の面より正常型，比較的不全型及び不全型と三型に分類する際に， それら各型と臨床所見との関係について検討してみた（第16表）．先ず若年高血圧者16例に於ては，正常型 は 4 例で好酸球減少率は良好でー $81 \%$, 比較的不全型は10例で最も多く好酸球減少率はー $53 \%$, 不全型は極 わて稀で 2 例，好酸球減少率も悪くー7\%であつた。 其の他颐床所見として比較的不全型は血圧動摇のはげ しい場合が多く，不全型では眼底所見及び心電図所見より動脈硬化が著明であつた．次に老年高血圧者27例 に於ては，正常型は 9 例で好酸球減少率はー51\%，比較的不全型は 12 例で好酸球減少率はー43\%，不全型は 6 例で好酸球娍少率はー37\%であつた。其の他臨床所見として血圧 $200 \mathrm{~mm} \mathrm{Hg}$ 前後を示すあのは比較的不全 型及び不全型に多くみられ，動脈硬化の特に強いものは不全型に多くみられた．即ち以上本態性高血圧者 43 例の中副等皮質機能正常型は13例 $(30 \%)$ ，比較的不全型は22例 $(51 \%)$ ，不全型は 8 例 $(19 \%)$ であり，結 
第16表 副腎皮質機能よりみた高血圧症の分類

\begin{tabular}{|c|c|c|c|c|c|}
\hline \multicolumn{2}{|c|}{ 副堅皮盾杆能 } & \multirow[t]{2}{*}{ 正常型 } & \multicolumn{2}{|c|}{ 比較的不全型 } & 不全型 \\
\hline \multirow{3}{*}{$\begin{array}{l}\text { ACTH } \\
\text { 頁苛時の } \\
\text { ステロ } \\
\text { 反底系 }\end{array}$} & $170 \mathrm{HCS}$ 变動 & & & & \\
\hline & 17 KS 变動 & & & & \\
\hline & 17KS分劃变動 & IIVVT个翌 & NV个型 & 不变型 & （不定） \\
\hline
\end{tabular}

\begin{tabular}{|c|c|c|c|c|c|c|}
\hline \multirow{3}{*}{ 言 } & \multirow{2}{*}{ 若 } & \multirow{2}{*}{$\begin{array}{l}\text { 例敷 } \\
\text { () 内 } \%\end{array}$} & \multirow{2}{*}{$4(25)$} & $6(38)$ & $4(25)$ & \multirow{2}{*}{$2(12)$} \\
\hline & & & & \multicolumn{2}{|c|}{$10(63)$} & \\
\hline & & \multirow{2}{*}{ 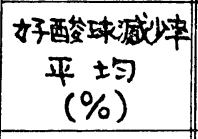 } & \multirow[b]{2}{*}{-81} & -52 & -53 & \multirow{2}{*}{-7} \\
\hline 血 & 年 & & & \multicolumn{2}{|c|}{-53} & \\
\hline 症 & 者 & 毝生動措の程度 & - & \multicolumn{2}{|c|}{+} & - \\
\hline$\frac{712}{9}$ & & 動脤硬化-程度 & + & \multicolumn{2}{|c|}{-} & H \\
\hline \multirow{6}{*}{$\begin{array}{c}\text { 臨 } \\
\text { 床 } \\
\text { 所 } \\
\text { 見 }\end{array}$} & \multirow{6}{*}{$\begin{array}{l}\text { 老 } \\
\text { 年 } \\
\text { 者 }\end{array}$} & 例數 & \multirow{2}{*}{$9(33)$} & $7(26)$ & $5(22)$ & \multirow{2}{*}{$6(19)$} \\
\hline & & () 内 $\%$ & & \multicolumn{2}{|c|}{$12(48)$} & \\
\hline & & \multirow{2}{*}{$\begin{array}{c}\text { 好酸球减少事 } \\
\text { 平均 } \\
(\%)\end{array}$} & \multirow{2}{*}{-51} & -45 & -41 & \multirow{2}{*}{-37} \\
\hline & & & & \multicolumn{2}{|c|}{-43} & \\
\hline & & 高血压の程度 & + & \multicolumn{2}{|c|}{ H } & $H$ \\
\hline & & 動蹒硕化の程度 & + & \multicolumn{2}{|c|}{+} & H \\
\hline
\end{tabular}

局副婜皮質機能低下を示すものが後二者を合せた70\%にみられた，以上の如く本態性高血圧者の中，動脈硬 化強く而も長期高血圧持続のものに皮質機能低下を示す場合が多いととは本態性高血圧発症に於ける副婜皮 質の意義究明の上に誠に興味深いととと考える。

\section{第 8 章 結論}

私は最高血圧 $150 \mathrm{mmHg}$ 以上の高血圧者男女につき尿中総 $17 \mathrm{OHCS}$, 総 $17 \mathrm{KS}$ 及び $17 \mathrm{KS}$ 分劃の測定を 行い，更に ACTH 負荷時のそれら变動量に於てみられる相関々係加ら本症に於ける副婜皮質機能特に予借 力の内容につき具体的な検討を行つた．尚これらと好酸球減少率，動脈硬化及び血圧の程度等臨床所見との 関係についても考察し次の如き成績を得た。

本態性高血圧者の 尿中総 $17 \mathrm{OHCS}$ 及び $17 \mathrm{KS}$ の 1 日排泄量及び ACTH 負荷によるそれらの変動量即 ち副等皮質子備力については特に健康人との間に差を認めないが，好酸球減少率は高血圧者でやや不良であ る. 又 ACTH 负荷による総 $17 \mathrm{OHCS}$ 及び総 $17 \mathrm{KS}$ の変動経過をみると高血圧者の一部に反応の異常乃 
至は遅延を示す異常反応型をみることができた。総 $17 \mathrm{OHCS}$ と総 $17 \mathrm{KS}$ 排泄量の間には健康人，高血圧 者共平行関係なく，更に ACTH 負荷による総 $17 \mathrm{OHCS}$, 総 $17 \mathrm{KS}$ 変動量を好酸球娍少率の間にも一定の 関係をみない. $17 \mathrm{KS}$ 分劃については血圧值の異る二時期について測定したが，その Pattern は大体恒常性 を示し，健康人と高血圧者との間には特に相違をみなかつた．ただ一般に老年者はIV + V 分劃が低值を示し， 高血圧者では特に男子に於て IV + V 分劃の増加傾向があることが分つた. 又 ACTH 負荷による $17 \mathrm{KS}$ 分 劃の変動をみると，健康人（特に若年者の場合）では大体副緊系分劃の増加をみたが，高血圧者に於てはこ の外, 性腺系分劃に増加をみるもの或は分劃に変動のないもの等三型の変動を示した. 又以上三変動型と総 $17 \mathrm{OHCS}$, 総 $17 \mathrm{KS}$ 変動量との間には一定の関係があり，それらは各々副腎皮質 response 或は皮質内代謝 面に於て異る意義を有する点から，本症の副緊皮質機能を正常型，比較的不全型及び不全型の三型に大別し， 更に以上各型と臨床所見との関連性とついて検討したところ，比較的不全型及び不全型等皮質機能低下を示 すむのが全体の70\%を占め，乙れらは正常型に較べ一般に動脈硬化強く，而も長期高血圧の持続する場合が 多かつた.

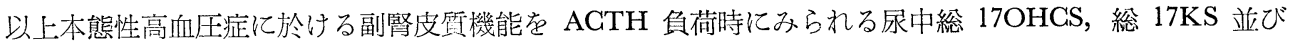
に $17 \mathrm{KS}$ 分劃の変動值，更には好酸球減少率より綜合的に検討した結果，本症の約 7 割に於て副婜皮質反 応性の低下乃至は代謝異常をきたしていることが分つた.

擱筆するに臨み終始御烈篤なる御指導御校閲を賜つた山田教授に深謝申し上げると共に，終始御鞭櫵御援 助下さいました中日病院長角田先生に愿く御礼申し上げます。

\section{文献}

1) Anderson : Am. J. physiol. $141: 393,1944$.

2) Bagget, B., Kinsella, R.A. \& Doisy, E.A. : J. Biol. Chem. $203:$ 1003, 1953.

3) Bayliss, R.I.S. \& Steinbeck, A. W. : Brit. M.J. $1: 486,1954$.

Best, W.R., Kark, R.M., Muehrcke, R.C. \& Stamaer, M. : J.A.M.A. 151 : 702, 1953. man, P.A., Doisy, P.P. \& Doisy, E.A. : Proc. Soc. Exper. Biol. \& Med. 72 : 297, 1949. Acta. Med. Scand. Suppl. $291: 53,1954$.

Bowers, R.F. : J.A.M.A. 154 : 394, 1954.

7) Bonner, C.D. : J.A.M.A. $148: 634,1952$.

, H., Ketz-

6) Birke, G. : J. Clin. Invest. $33:$ 1524, $1954 . \quad$ 10) Bruger \& Rosentantz, H. : Am. J. Med. Science $208: 212,1944$. 11) Burstein, S., Savard, K. \& Dorfman, R. I. : Endocrinology $53: 88,1953 . \quad$ 12) Butt, W. R. : Lancet 6644, 1950. 13) Christy, N.P., Wallace, E.Z. \& Jailer, J.W. : J. Clin. Invest. $34: 899,1955 . \quad 14)$ Chwalla, R. : Endocrinology $29: 129,1952 . \quad 15)$ Cohen, S. E. : J. Biol. Chem. $192: 147,1951$. 16) Conn, J.W. : Ann. Int. Med. $44: 1,1956 . \quad 17)$ David, H. \& Solomon : J. Gerontol. $4: 304,1950$. 18) Dingemanse, E. \& Huis, L. G. : J. Clin. Endocrinol $6: 535,1946 . \quad 19)$ Dingemanse, E., Huis, L. G. \& Hortoghkatz, S. L. : J. Clin. Endocrinol. and Metab. $12: 66,1952 . \quad 20)$ Dobriner, K. : J. Clin. Invest. $33: 222,1954 . \quad 21)$ Drekter, I.J. : J. Clin. Endocrinol. $7: 12,1947 . \quad 22)$ Euler, U.S. : Noradrenaline. Thomas, Springfield, III, $1956 . \quad 23)$ Fisher, B. \& Fisher, E.R. : Am. J. Med. Science 221 : 121, 1951. $\quad 24)$ Forsham, P. H. : Ciba Foundation Collogia on Endocrinology 8, 279 J \& A. Charchill Ltd. London $1955 . \quad$ 25) Frank, H. \& Tyler: J. Am. Geriatr. Society $3: 79,1955$. 26) Genest, J. : Science $123: 503,1956$. 27) Goldenberg, M. : Am. J. Med. $10: 627,1951$. Green, D. M. : Ann. Int. Med. $39: 333,1953 . \quad$ 29) Howard, G. \& Hanley : Lancet $6856: 199,1955$. 30) Ich!kawa, T., Wakuand, M. \& Ishimoto, M. : Endocrinol. japonica $2: 87,1955$. 31) Jailer, J.W., Gold, J. J., Wiele, R. V. \& Lieberman, S. : J. Clin. Invest. 34 : 1639, 1955. 32) Jenkins, D., Forsham, P.H., Laidlaw, J.C., Reddy, W.J. \& Thorn, G.W. : Am. J. Med. 181 : 3, 1955.

33) Kappas, A., Dobriner, K. \& Gallagher, T. F. : J. Glin. Invest. 34 : 1559, 1955.

34) Kappas, A. \& Gallapher, T.F. : J. Clin. 
Invest. $34: 1566,1955$.

35) Keinesberg, E. : J. Clin. Endocrinol. $9: 426,1949$.

36) Keith, Wagener \& Barker : Am. J. Med. Science $197: 332$, $1939 . \quad 37)$ Kepler, E.J. \& Mason, H.L. : J. Clin. Endocrinol. $7: 543,1947$

38) Leathem \& Drill : Endocrinology $33: 112,1944$.

39) Levine, R. \& Fritz, I. : Am. J. physiol. $165: 456,1951 . \quad 40)$ Lieberman, S. \& Te!ch, S. : J. Clin. Endocrinol. \& Metab. $13: 1140,1953 . \quad$ 41) Locke, W., Talbot, N.B., Jones, H.S. \& Worcester, J. : J. Clin. Invest. $30: 325,1951$. 42) Long, C. N. H., Fry, E. G. \& Brobeck, J.R. : Proc. Soc. Exper. Biol. \& Med. 73 : $609,1950$. 43) Masuda, M. : J. Glin. Endocrinol. \& Metab. $17: 1181,1957$.

44) Pearson, S. \& Giaccone : J. Glin. Endocrinol. $8: 618$, $1948 . \quad 45)$ Pincus, G. : J. Clin. Endocrinol. $8: 221$, 1948. 46) Polley, H. F. \& Mason, H. L. : J.A.M.A. $113: 1474,1950 . \quad$ 47) Pond, M.H. : London Dennis Dobson P. 53. 48) Reddy, W. J., Jenkins, D. \& Thorn, G. W. : Metabolism 1:511, 1952. 49) Renold, A.E., Jenkins, D., Forsham, P.H. \& Thorn, G.W. : J. Glin. Endocrinol. 12 : 763, 1952.

Robinson, A. M. : Rec. Prog. Horm. Res. $9: 163,1954 . \quad 51)$ Romanott, L. P. : Endocrinology $45: 10$, 1949. 52) Rosenkrantz, H., Dorfman, R. \& Pincus, G. : J. Clin. Endocrinol. \& Metab. 13 : $568,1953$. 53) Rud \& Finn : Acta psychiat et Neurol. Supp. 40, 1947.

54) Savard, K., Burstein, S., Rosenkrantz, H. \& Dorfman, R. I. : J. Biol. Chem. $202: 717,1953 . \quad 55)$ Schneider, J. J. \& Horstman, P. M. : J. Biol. Chem. $196:$ 6229, $1952 . \quad 56)$ Selye, H. : J. Clin. Endocrinol. $6: 117,1946$. 57) Smith, R.W., Mellinger, R.C. \& Patti, A.A. : J. Clin. Endocrinol. \& Metab. 14 : 336, 1954.

58) Thorn, G.W., Forsham, P.H., Pronty, F.T.G. \& Hills, A. G. : J.A.M.A. $137: 1005,1948$.

59) Thorn, G. W. : Am. J. Med. $10: 595,1951 . \quad 60)$ Thorn, G.W., Jensen, D. \& Laidlaw, J.C. : Rec. Prog. Horm. Res. $8: 171,1953$. 61) Tobian, L. : J. Clin. Endocrinology $9: 319,1949 . \quad 62)$ Venning, E. H. : J. Clin. Endocrinology

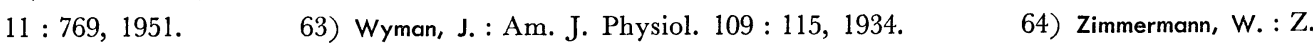
Physiol. Chem. 233, 257, $1935 . \quad$ 65) Zygmuntowicz, A. S., Wood, M., Christo, E. \& Jalbot, N. B. : J. Clin. Endocrinol. $11: 578,1951.666)$ 安達：日産婦会誌，7:1507，眧30. 67）赤須：最新 医学, $13: 2019$, 昭 33.68$)$ 日置 : 最新医学, $12: 432$, 炤32. 69$)$ 日置 : 最新医学, $12: 723$, 昭32. 70) 福井：骖療，11：59，昭33. 71）幸田：日循環会誌，19：124，昭30. 72） 熊谷: 日内分泌会誌，31：537，昭30, 73) 三宅：日内分必会誌，26:122, 昭25.74) 三宅 : 診療，7:383，眧29. 75) 中尾：副腎皮質ホルモン，医学書院，昭27. 誌，31:205，炤30。 77）興津：日内分泌会誌，33:996，炤33.

76）西川：日内分爫会 79) 大野：日内分泌会誌，31:337，昭30. 78）大野：内分泌のつどい, 第 3 集，P.613 昭28. 81) 大島 : 最新医学, $13: 1701$, 炤33。 82$)$ 瀬戸岡 : 最新医学, $13: 73$, 昭 33 . 83) 昭28. 81) 大島 : 最新医学, $13: 1701$, 炤33。 82$)$ 瀬戸岡 : 最新医学, $13: 73$, 昭33. 83) 下村 : 名古屋医学，74:231，昭32. 84）鈴木：日内分泌会誌，34:768，炤33. 85）鷹津：日 循環会誌, $17: 328$, 昭 28 .

86）鳥居：内分泌のつどい，第 7 集，P.177. 